\title{
Impediments of Green Finance Adoption System: Linking Economy and Environment
}

\author{
Kanwal Iqbal Khan ${ }^{1}{ }^{\infty}$, Mário Nuno Mata ${ }^{2 *^{*}}$, José Moleiro Martins ${ }^{2,3}{ }^{\infty}$, Adeel Nasir ${ }^{4 *}$, \\ Rui Miguel Dantas ${ }^{2} \odot$, Anabela Batista Correia ${ }^{2}{ }^{\circ}$, Mahr Umar Saghir ${ }^{1}$ \\ ${ }^{1}$ Institute of Business \& Management, University of Engineering and Technology, Lahore 54000, Pakistan \\ ${ }^{2}$ ISCAL-Instituto Superior de Contabilidade e Administração de Lisboa, Instituto Politécnico de Lisboa, Avenida Miguel Bombarda 20 , Lisboa, Portugal. \\ ${ }^{3}$ Instituto Universitário de Lisboa (ISCTE-IUL), Business Research Unit (BRU-IUL), 1069-035 Lisboa, Portugal. \\ ${ }^{4}$ Department of Management Sciences, Lahore College for Women University, Lahore 54000, Pakistan.
}

\begin{abstract}
Environmental deregulation has become a severe concern for public health around the world Increased pollution and ecological degradation have diverted attention towards adopting green practices, which can be possible if the sustainable green finance system is implemented in its true spirit. But previous studies reported certain factors affecting its implementation process, particularly in developing countries. This study aims to identify and quantify the barriers to adopting a green finance system. First, it identified twenty barriers through an extensive literature review and semi-structured interviews with experts in the fields of financial management, economics, and environmental sciences. Later, eighteen factors were finalized by the consensus of panel experts, which was further used to analyze their interrelationship through Interpretive Structural Modelling (ISM). Using MICMAC analysis, these barriers were categorized based on their diving-dependence powers. Finally, the conceptual ISM model is developed that provides a clear picture of the impediments to the green finance adoption system and their flow relationship among the identified barriers at different levels. The findings suggest that global level factors: lack of pressure from international organizations and unavailability of globally acceptable green criteria are critical to the prevalence of other factors that indicate its centrality to effectively implementing the green finance system. The developed model helps in designing, implementing, and promoting eco-friendly projects. It is also recommended that an appropriate framework is required to be developed at global, country, organizational, and individual levels to deal with the barriers of the green finance adoption system.
\end{abstract}

Keywords:

Environmental Degradation;

Green Finance System;

Public Health;

Economic System;

Pollution;

MICMAC Analysis;

Green Criterion;

Eco-friendly Projects.

Article History:

$\begin{array}{llll}\text { Received: } & 24 & \text { July } & 2021 \\ \text { Revised: } & 22 & \text { December } & 2021 \\ \text { Accepted: } & 05 & \text { January } & 2022 \\ \text { Available online: } & 27 & \text { February } & 2022\end{array}$

\section{1- Introduction}

Globalization brings prosperity to nations through its unfettered cross-border flow of goods and capital, but at the same time, its effect on the environment is becoming highly controversial [1]. Now globalization is turning into a reason for pollution to spread and impact people's lives around the globe [2]. According to the World Bank report, the cost related to the health damage from ambient air pollution is about $\$ 5.7$ trillion, accounting for $4.8 \%$ of the world GDP. In contrast, the cost associated with premature mortality and morbidity is about 5 to $14 \%$ of its GDPs. Therefore, many global and local actors raise their voicing concerns against environmental degradation, especially after the famous Paris

*CONTACT: mnmata@iscal.ipl.pt; adeel.nasir@lcwu.edu.pk

DOI: http://dx.doi.org/10.28991/ESJ-2022-06-02-02

(C) 2022 by the authors. Licensee ESJ, Italy. This is an open access article under the terms and conditions of the Creative Commons Attribution (CC-BY) license (https://creativecommons.org/licenses/by/4.0/). 
climate agreement 2015 [3]. Where all the member countries unanimously agreed to reduce $\mathrm{CO} 2$ emissions, which is a severe threat to the world and maintains the threshold of $2{ }^{\circ} \mathrm{C}$ [4]. They also emphasized the need for countries to adopt green practices and to invest 53 trillion dollars by 2035 [5].

"Green Practices" are ideologically eco-friendly practices that support the green culture without disrupting sustainable economic growth and corporate profits $[6,7]$. Green practices can be promoted through a green finance system that stimulates sustainable development and reduces greenhouse gases and harmful pollutants during the manufacturing process [8]. It reshapes the organizational routine for governing and lending matters. It also plays an imperative role in reducing the catastrophic consequences of environmental degradation that may contribute to sustainable economic development [9]. That is why every country wanted to adopt a green finance system but faced various responses concerning its implementation. The developed economies may quickly adopt the new financing methods compared to the emerging economies because a significantly larger amount of investment is required for that purpose. However, lowincome countries already possess limited financial resources [10].

Therefore, the green finance system faces a wide range of challenges during the adoption process, where the paradigm has shifted from a traditional to a green system [11]. It is subjected to economic, political, and technological uncertainties, particularly in developing countries [12]. Sometimes, the system cannot be implemented due to the lack of policy framework, inconsistent government policy, lack of interest of the private partners, limited technical knowledge, and focus on the short-term investment plans [13, 14]. Further, no appropriate structure is available to securitize the projects for financing; no proper strategy has been developed to address the policy matters regarding screening and selecting the projects [15]. Long-term investments and infrastructure financing in energy renewal projects are also lacking in the developing world [16]. The private sector is not interested in such types of long-term projects, so there is a need to use monetary policy as a tool to encourage green investment.

The public-private partnership can also establish a healthy link between innovation and technological development that accelerates the economy to explore untapped opportunities for green growth. But the private sector is not interested in the green project due to the low rate of return and high risk associated with it. On the other hand, organizations can use green finance as a tool to meet their CSR requirements [17]. They can introduce green financing instruments like a community-based green fund, green bonds, and securities to promote green projects [18]. But still, due to a lack of technical knowledge and innovation, they fail to get the desired results. Similarly, financial institutions can also develop a green banking system and introduce carbon market instruments and ecological bonds to bolster green financing. In addition, they can introduce green financing and a cost-sharing framework to deal with capital constraints [19]. But due to the limited involvement of key actors (financial institutions, economists, governments, manufacturers, investors, infrastructural operators, researchers), they are unable to establish a collaborative network.

The technically advanced countries like Japan, China, and South Korea have attained sustainable development goals by amalgamating green innovation and green finance [20]. The developed countries also promote high productivity low carbon projects [21]. At the same time, developing countries are still struggling to achieve financial stability while meeting ecological concerns. They face a major challenge to establish a policy framework for the green finance system [22]. There is currently no strategy to identify the right project, develop the plan for public-private partnerships, propose the financing structure, and decide the loan terms and conditions. For that purpose, effective long-term planning, budgeting, project implementation plans, and risk management strategies are needed to be developed. But the focus of the previous studies on these aspects is limited.

Therefore, developing countries need to push their financial sector to establish and implement a green finance system to achieve sustainable green growth through economics and environmental harmony. But, the financial sector in these countries recently faced several barriers during the adoption process, which must be addressed. The current study is conducted to (1) identify the impediments to the adoption of green finance from the prior literature; (2) apprehend the perspective of key actors from the financial institutions about the key obstacles; (3) develop a multi-hierarchical model to explain the relationship between the barriers; and (4) propose a framework to support sustainable green finance system for the developing countries. The findings of the study contribute to the emerging literature of finance, economics, and environmental sciences. First, it emphasizes that the impediments of the green finance adoption system cannot be fully understood without blending these three subjects. Second, it develops a multi-hierarchical model to explain the relationship between the barriers and then proposes a conceptual framework that can add to the existing literature on the green finance adoption system of the developing countries.

\section{2- Literature Review}

The concept of green finance is broadly defined in the context of finance, economic and environmental sciences, but still, there is no consensus on a particular definition [23]. Generally, it includes financial expenses for renewable energy programs that support sustainable growth. It is a vital aspect of the low-carbon green energy economy since it links the financial sector with sustainable economic development [24]. It is a connection between global sustainability goals as well as the financial industry. As per the Green Finance Research Group of the G20, green finance facilitates funding to 
the projects that create a positive environmental impact on the larger perspective of sustainable development [25]. Green financing covers the term 'climate finance' (renewable energy, reduced carbon emission, energy savings, and climate adaptation), including broader natural resource management funding to support green development and preserve and rebuild natural landscapes, habitat and water quality, wildlife and biodiversity. Climate finance is an environmental component of finance for incorporating social and ecological governance aspects across financial decisions [26].

Green finance includes carbon, climate, and renewable finance, but its scope is not restricted to these concepts [27]. In the banking sector, climate finance provides products and services, taking into account environmental considerations across lending decisions, tracking, and risk assessment procedures, given to facilitate ecologically sound investment and promote low-carbon initiatives, ventures, and businesses [28]. Green funding is also used synonymously with renewable finance. But, in reality, green finance is a broader framework, covering far beyond investments [29]. The most critical aspect is the running cost of green investment, which is not a part of the concept of green investment but is covered in it. Most importantly, it covers the planning cost of projects and land purchases; all of these are important may face particular funding difficulties. Green finance applies to a broader perspective of sustainability objectives, such as reducing greenhouse gas emission, industrial waste management, prevention from pollutants [30],

Green finance prospects contain financial market instruments like bonds, bank loans for renewables, reduced carbon transport, energy efficiency; green capital funds (infrastructure management funds and economic indicators); social disaster environment liability insurance; and carbon markets [30]. The key development actors include green bonds, green investments (investing responsibly), and financing of green projects. More specifically, firm investments favor green ventures and the lease of bank loans through a green bond. The use of unshackled balance sheets can, later on, be offered to different green finance projects, particularly for projects related to infrastructure [31]. In addition, online banking, renewable lending, cash-saving equipment, green credit cards, solar and wind energy projects, and mobile banking have become broadly accepted financial techniques [32]. Table 1 discusses the subject area of green finance.

Table 1. Subject area for green finance

\begin{tabular}{|c|c|c|}
\hline Fields of Study & Key Terms & References \\
\hline $\begin{array}{l}\text { Financial } \\
\text { Management }\end{array}$ & $\begin{array}{l}\text { Green investment funds, green lending, green bonds, green banking } \\
\text { system, green bonds, forestry securitizations, nature-linked securities, } \\
\text { carbon trading, green tariffs, carbon market instruments, community- } \\
\text { based green fund. }\end{array}$ & $\begin{array}{l}\text { Wang \& Zhi (2016), Peng et al. (2018), Haleem } \\
\text { et al. (2012) Taghizadeh-Hesary \& Yoshino } \\
\text { (2019) and Azhgaliyeva (2019) [18, 30, 33-35] }\end{array}$ \\
\hline Economics & $\begin{array}{l}\text { Green economy, green technology, green growth, infrastructure } \\
\text { investment, credit guarantee schemes, sustainable development goals, } \\
\text { low-carbon economy }\end{array}$ & $\begin{array}{l}\text { Peng et al. (2018), Jha \& Bhome (2013) and } \\
\text { Dowson et al. (2012) }[32,34,36]\end{array}$ \\
\hline $\begin{array}{l}\text { Environmental } \\
\text { Sciences }\end{array}$ & $\begin{array}{l}\text { Carbon finance, climate finance, environmental and biodiversity funds, } \\
\text { debt-for environment swaps, climate change, environmental } \\
\text { sustainability, renewable energy, environmental protection, energy-smart } \\
\text { technology, clean energy, small green energy projects. }\end{array}$ & $\begin{array}{l}\text { Sachs et al. (2019) and Yoshino et al. (2020), } \\
\text { and Dowson et al. (2012) }[5,14,36]\end{array}$ \\
\hline
\end{tabular}

Green Finance is a crucial component to attain green growth related to healthy economic development is essential in achieving sustainable development goals [37]. The researchers suggest that the rolling force and objective of green development is to increase the capacity of a nation to produce products in a manner that overrides environmental degradation, utilizes green products and expertise, and spreads assets [38]. Therefore, any integrated investment decision of a financial instrument applies to green finance, which involves the transaction of debt, grant, equity, selling, and green products acquisition [39]. Although both the definitions have a slight difference, both the terms have a similar core of financing projects to sustain and protect the climate [3].

\section{2-1- Barriers to Sustainable Green Finance System Adoption}

The greening of the economy significantly depends on the actions of the financial sector, but prior literature identified certain obstacles in implementing this system [26, 31]. Green banking and renewable finance are indeed niche sectors that can induce companies to follow green practices but still, it requires extensive effort to implement this system [40]. Prior studies identified impediments to the green finance adoption system [41]. The foremost obstacle is the lack of education and awareness. There is a need to raise awareness about green finance at all levels, identify the green projects, and verify whether they provide green finance or not, i.e., determining green criteria is crucial [8]. For countries comprising of massive fossil fuel sector, providing enough lucrative incentives for sustainable entrepreneurs is more troublesome. In developing markets, the burden for establishing such opportunities also rests with governments who already have weakened bureaucratic capability and poor regulatory structure [42].

Political laws and legislation often hinder green innovation activities due to their strict existence and lack of transparency. Organizations are discouraged in the absence of political funding for green innovation programs [43]. Significant variations in green financing adversely impact emission consumption and the nonrenewable energy market. The continuity and resilience of sustainable economic policy are crucial to eliminating pollution [44]. Soedarmono et al. 
(2011) [45] suggested that the economic environment negatively impacts stable banking. Comparative studies indicate that climate change has dramatically decreased bank stability [27]. The damage to the environment and climatic conditions uncertainties threaten the viability of banks, insurance companies, and other financial players; therefore, central banking needs to be concerned [31]. Past research contains a very small number of studies demonstrating the association between green finance and commercial banking stability [27]. Banks are unaware of the complete picture of environmental risks' effects [41]. SMEs especially are at the back foot when it comes to implementing green practices. New technologies and finances are essential for green technologies, and small and medium-sized businesses are limited mainly by resources [46]. Handling environmental impacts generated by economic growth is easier in developed nations, as the guidelines to be practiced by corporations are defined and require compliance [38]. Developing economies are a wide and varied community. The unique condition of underdeveloped nations with inadequate or evolving financial markets makes it essential to recognize their interests, needs, and strategies to green finance [47].

Typically, increased prices related to the purchase of green products also cause companies not to implement green policies, which is more common in small and medium-sized businesses [48]. Green sectors and innovations are going through various lifespan stages, demanding distinct capital investments from different financial institutions [49]. The level of competence needed for green innovation is quite large and complex concerning other technological advancements [50]. Significant financial obstacles in green innovation for businesses involve less return concerning investment in renewable technologies [51]. The creation of the pollution prevention sector requires a considerable amount of initial private investment, but it has slowed and prolonged repaying period. The related green economy policies should reduce the financial constraint that the government has to face [33]. Many creditors and institutional firms are hesitant to participate in renewable energy ventures since they deem them to face too significant a risk and the return on capital to be somewhat poor compared to alternative investment projects [18]. Table 2 presents the summarised list of the barriers to the green finance adoption system identified from the prior literature.

Table 2. List of barriers to green finance adoption

\begin{tabular}{|c|c|c|}
\hline Barrier & Description & References \\
\hline $\begin{array}{l}\text { Knowledge about the } \\
\text { "Green" concept }\end{array}$ & $\begin{array}{l}\text { People do not have a clear idea about the "Green" concept due to limited } \\
\text { knowledge, lack of green literature, and information diffusion. That is why } \\
\text { they are not familiar with the prospects of green philosophy. }\end{array}$ & $\begin{array}{l}\text { Abuzeinab et al. (2017) and Mumtaz \& } \\
\text { Smith }(2019)[52,53]\end{array}$ \\
\hline $\begin{array}{l}\text { Unsupportive organizational } \\
\text { structure }\end{array}$ & $\begin{array}{l}\text { The current practices and frameworks of the companies are very hostile to } \\
\text { the green finance environment and thus find it difficult to adopt them. }\end{array}$ & $\begin{array}{l}\text { Ren et al. (2020), and Rahman et al., } \\
(2020)[44,54]\end{array}$ \\
\hline Lack of employee Training & $\begin{array}{l}\text { There is a lack of training programs to adopt green practices due to limited } \\
\text { resources. }\end{array}$ & $\begin{array}{l}\text { Soedarmono et al. (2011), and Gupta \& } \\
\text { Barua }(2018)[45,46]\end{array}$ \\
\hline $\begin{array}{l}\text { Inadequate analytical } \\
\text { capability and training }\end{array}$ & $\begin{array}{l}\text { Presence of insufficient analytical capacity and training for the green } \\
\text { practices among the citizens. }\end{array}$ & $\begin{array}{l}\text { Soedarmono et al. (2011) and Mohd \& } \\
\text { Kaushal (2018) }[41,45]\end{array}$ \\
\hline Risk and process issues & $\begin{array}{l}\text { There is a lack of policies and procedures, so high risk is involved in this } \\
\text { new emerging system; that is why individuals and organizations are } \\
\text { hesitant to be a part of it. }\end{array}$ & $\begin{array}{l}\text { Wang et al. (2020) and Choi (2009) [1, } \\
55]\end{array}$ \\
\hline $\begin{array}{l}\text { Low return on investment as } \\
\text { compared to the cost of } \\
\text { green innovations }\end{array}$ & $\begin{array}{l}\text { Green technologies are costly and require a large amount of investment. } \\
\text { But the return on investment is meager compared to the cost of green } \\
\text { innovations. }\end{array}$ & $\begin{array}{l}\text { Taghizadeh-Hesary \& Yoshino (2019) } \\
\text { and Matus et al. (2012) [18, 51] }\end{array}$ \\
\hline $\begin{array}{l}\text { Insufficient existing } \\
\text { technological structure }\end{array}$ & $\begin{array}{l}\text { The existing technological structure is insufficient to support green } \\
\text { practices, so it is a severe threat to attaining green finance. }\end{array}$ & $\begin{array}{l}\text { Rahman et al., (2020) and Samari et al., } \\
(2013)[54,56]\end{array}$ \\
\hline $\begin{array}{l}\text { Complexity in technology to } \\
\text { support }\end{array}$ & $\begin{array}{l}\text { The technology required to support green practices is complex and requires } \\
\text { a developed organizational structure and expertise for its implementation. }\end{array}$ & $\begin{array}{l}\text { Philip (2020) and Ghisetti et al. (2017) } \\
{[39,48]}\end{array}$ \\
\hline Lack of technical expertise & $\begin{array}{l}\text { The lack of technical structure results from a lack of technical expertise, } \\
\text { eventually hindering green finance implementation. }\end{array}$ & $\begin{array}{l}\text { Philip (2020), Ghisetti et al. (2017) and } \\
\text { Nguyen et al. (2019) [39, 48, 57] }\end{array}$ \\
\hline $\begin{array}{l}\text { Poor communication with } \\
\text { external stakeholders }\end{array}$ & $\begin{array}{l}\text { There is a lack of coordination among the stakeholders, and as a result, } \\
\text { they are not aware of their responsibilities. }\end{array}$ & Choi (2009), Peng et al. (2018) $[34,55]$ \\
\hline $\begin{array}{l}\text { Lack of interest in the } \\
\text { banking sector }\end{array}$ & $\begin{array}{l}\text { The banking sector shows a lack of interest in implementing the } \\
\text { sustainable green finance system. }\end{array}$ & $\begin{array}{l}\text { Sachs et al. (2019), Taghizadeh-Hesary } \\
\& \text { Yoshino (2019) and Soedarmono et } \\
\text { al. (2011) }[5,18,45]\end{array}$ \\
\hline $\begin{array}{l}\text { Lack of private sector } \\
\text { involvement }\end{array}$ & $\begin{array}{l}\text { The private sector has little participation in green finance movements due } \\
\text { to high risk and low return. }\end{array}$ & $\begin{array}{l}\text { Taghizadeh-Hesary \& Yoshino (2019), } \\
\text { Wang \& Zhi }(2016) \text { and Yoshino et al. } \\
(2019)[18,33,58]\end{array}$ \\
\hline Political Instability & $\begin{array}{l}\text { Political instability also causes hindrances on the path to green finance } \\
\text { adoption. }\end{array}$ & $\begin{array}{l}\text { Samari et al. (2013) and Taghizadeh- } \\
\text { Hesary \& Yoshino }(2019)[18,56]\end{array}$ \\
\hline $\begin{array}{l}\text { Uncertain economic } \\
\text { condition }\end{array}$ & $\begin{array}{l}\text { Uncertain economic situation also stands as an obstacle in sustainable } \\
\text { green finance system adoption. }\end{array}$ & $\begin{array}{l}\text { Runhaar et al. (2008) and Ren et al. } \\
(2020)[43,44]\end{array}$ \\
\hline $\begin{array}{l}\text { Lack of provision for } \\
\text { government subsidies }\end{array}$ & $\begin{array}{l}\text { The government provides very few subsidies, so people are hesitant to } \\
\text { promote green policies. }\end{array}$ & $\begin{array}{l}\text { Samari et al. (2013) and Abuzeinab et } \\
\text { al. (2017) }[52,56]\end{array}$ \\
\hline $\begin{array}{l}\text { Lack of pressure from } \\
\text { global organizations }\end{array}$ & $\begin{array}{l}\text { Absence of pressure from regional and global organizations for the } \\
\text { transition to green practices. }\end{array}$ & $\begin{array}{l}\text { Dowson et al. (2012) and Guild (2020) } \\
{[36,42]}\end{array}$ \\
\hline $\begin{array}{l}\text { Lack of globally available } \\
\text { green criterion }\end{array}$ & $\begin{array}{l}\text { Another obstacle to adopting green practices is that there are no fixed } \\
\text { standards for determining green practices. }\end{array}$ & $\begin{array}{l}\text { Chowdhury et al. (2013), Zubair } \\
\text { Mumtaz et al. (2019), and Sareen \& } \\
\text { Sharma }(2021)[8,38,59]\end{array}$ \\
\hline
\end{tabular}




\section{3- Materials and Methods}

This study aims to identify the impediments to adopting the sustainable green finance system in developing countries like Pakistan and find out how these identified factors are related to each other. For that purpose, we collected the data in two phases. In phase 1, the extensive literature review was conducted systematically in two steps: (1) Scopus database was used to collect the metadata through the following search strings \{(TITLE-ABS-KEY ("green finance" or "climate finance" or "green economy" or "green bonds" or "community-based green fund" or "sustainable green growth" or "green banking system" or "sustainable development" or "financial system" or "climate change" or "environmental protection" or "carbon market instruments")) \} without imposing the time limitation. We had withdrawn all most all the significant documents (articles, books, book chapters, etc.) related to the topic under study. (2) Google scholar database was used to extract more related literature about the factors considered as obstacles or enablers in the implementation process of green finance without restricting the context of developing countries, which adds more relevant literature. In the second phase, information was collected by conducting interviews with the field experts to get more information about the barriers pertinent to the developing countries. Figure 1 explains the research methodology of the study.

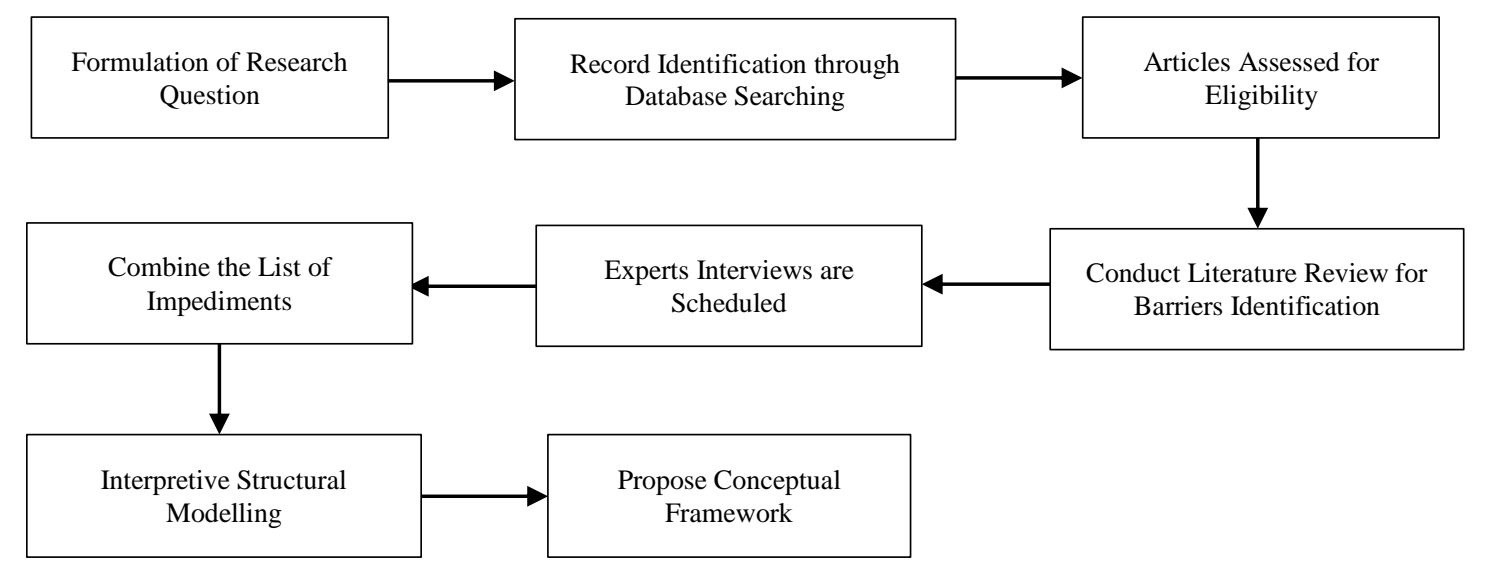

Figure 1. Flowchart of the research methodology

\section{3-1- Interviews}

The purpose of using a qualitative technique is to explore more obstacles in the context of developing countries like Pakistan. Twenty-one semi-structured interviews were initiated to create a better understanding of the concept. Telephonic and face-to-face interviews were conducted to get more information about the barriers in establishing green finance strategies in low-income countries. The study has used proper interview protocol for data collection, including the questions regarding green finance, criteria for assessing green projects, current policies (terms and conditions, interest rates, duration, etc.), challenges in adoption, and future recommendations. All the participants have extensive experience in their fields, notably have significant knowledge about the financial, economic, and environmental policies. The websites of their corresponding firms were also visited to familiarise them with their primary responsibilities and experience in the field; see Appendix A (Table A1) for the interviewees' detailed characteristics.

Data were collected in recorded audios, later transcribed in English and analyzed through word cloud (see Figures 2 and 3). Figure 2 depicts respondents' knowledge about the concept, while figure 3 provides information related to green finance impediments. Word cloud extracted the most repeated words from the data, highlighting the interviewees' most common phrases or concepts during the interview sessions. The Gioia technique was used to systematically analyze the raw interview data to explore emerging concepts, trends, themes, and dimensions [60]. First, interviews were coded based on the interviewees' statements, and these codes were categorized as first-order coding. We extracted specific patterns from the first-order concepts in the second phase and then abstractly generated second-order themes. After that, we create aggregate themes that explain various concepts and linkages among them [61]. Figure 4 presents the data structure of the interviews. 


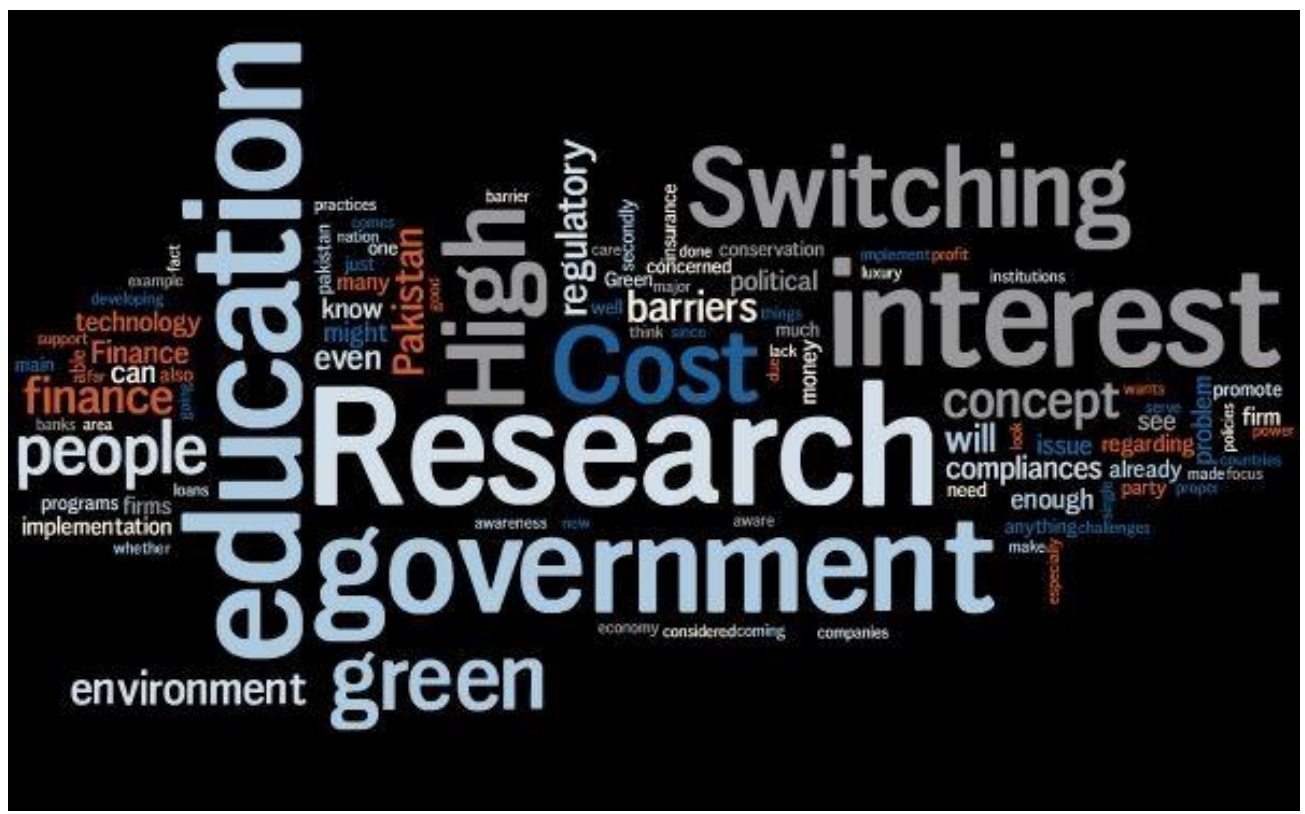

Figure 2. Knowledge about the concept

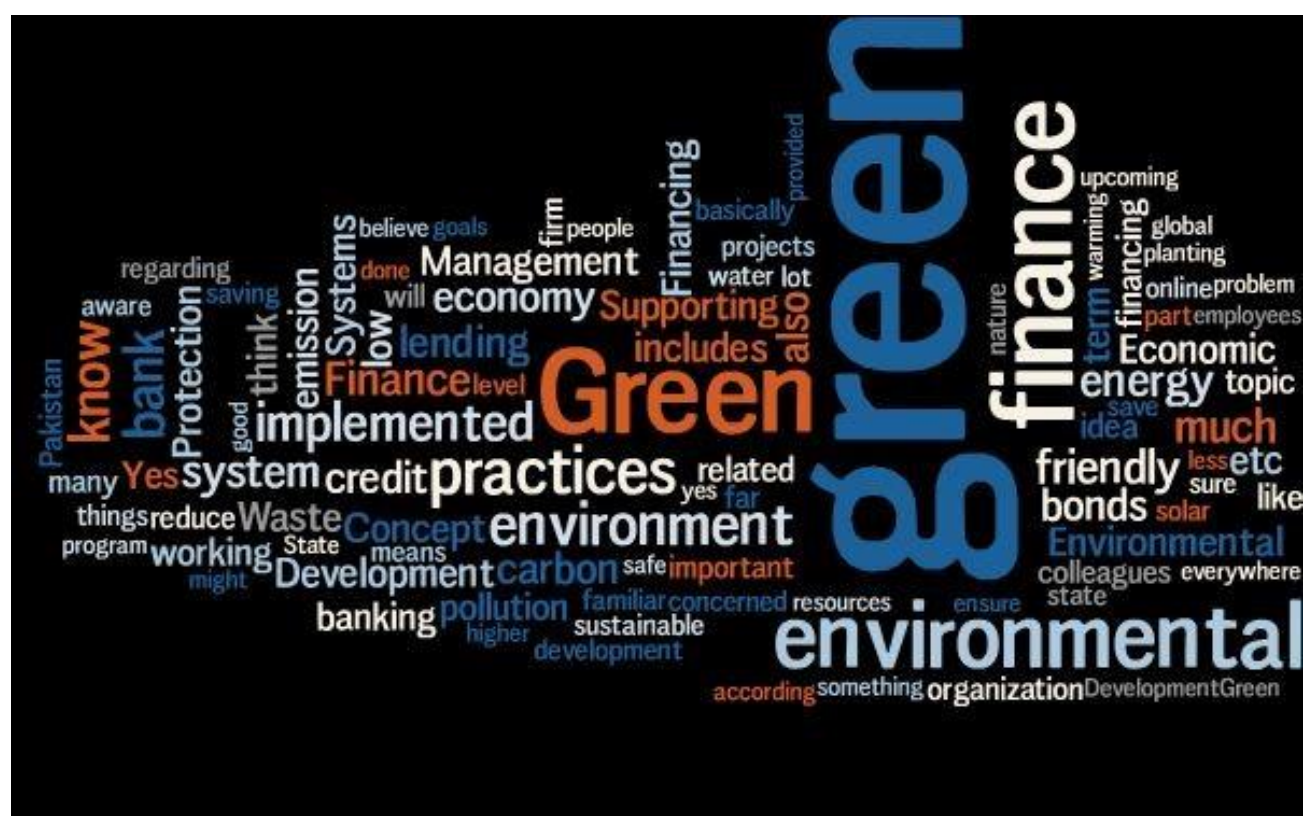

Figure 3. Impediments to Green Finance

Here we applied the Gioia methodology to explore new barriers to green finance implementation, specifically in developing countries, its future trends, and challenges. Figure 4 exhibited the summarised list of obstacles identified from the interview data not reported in the literature review. The interviews identified three essential barriers (high switching cost, insufficient research on topic, and green finance regulatory body). The aggregate dimension of "Absence of Regulatory Body" is extracted from the second-order themes of "Regulatory compliance Violations", "Need for Green Legislation", and "Lack of Government Interest", which are extracted from interviewers' statements presented in the first order theme. The second significant obstacle in the way of implementing a green finance system in developing countries like Pakistan is the "Insufficient Research on the Topic". This aggregate dimension is extracted by combining the secondorder themes of "Vague Green Finance Definition" and "Lack of Awareness and Education".

Last essential impediment that developing countries face is "High Switching Cost", which is derived from the secondorder themes of "High Reliance on Fossil Fuels", "Lack of Funding", Improper Resource Planning", and "Paradoxical Conditions of Developmental Projects". The second-order themes are also developed based on first-order themes extracted from the interviewers' statements. Later, we combined the barriers extracted from the literature with the interview data and then explored the relationship between the identified obstacles through the Interpretive Structural Modelling (ISM) technique. 


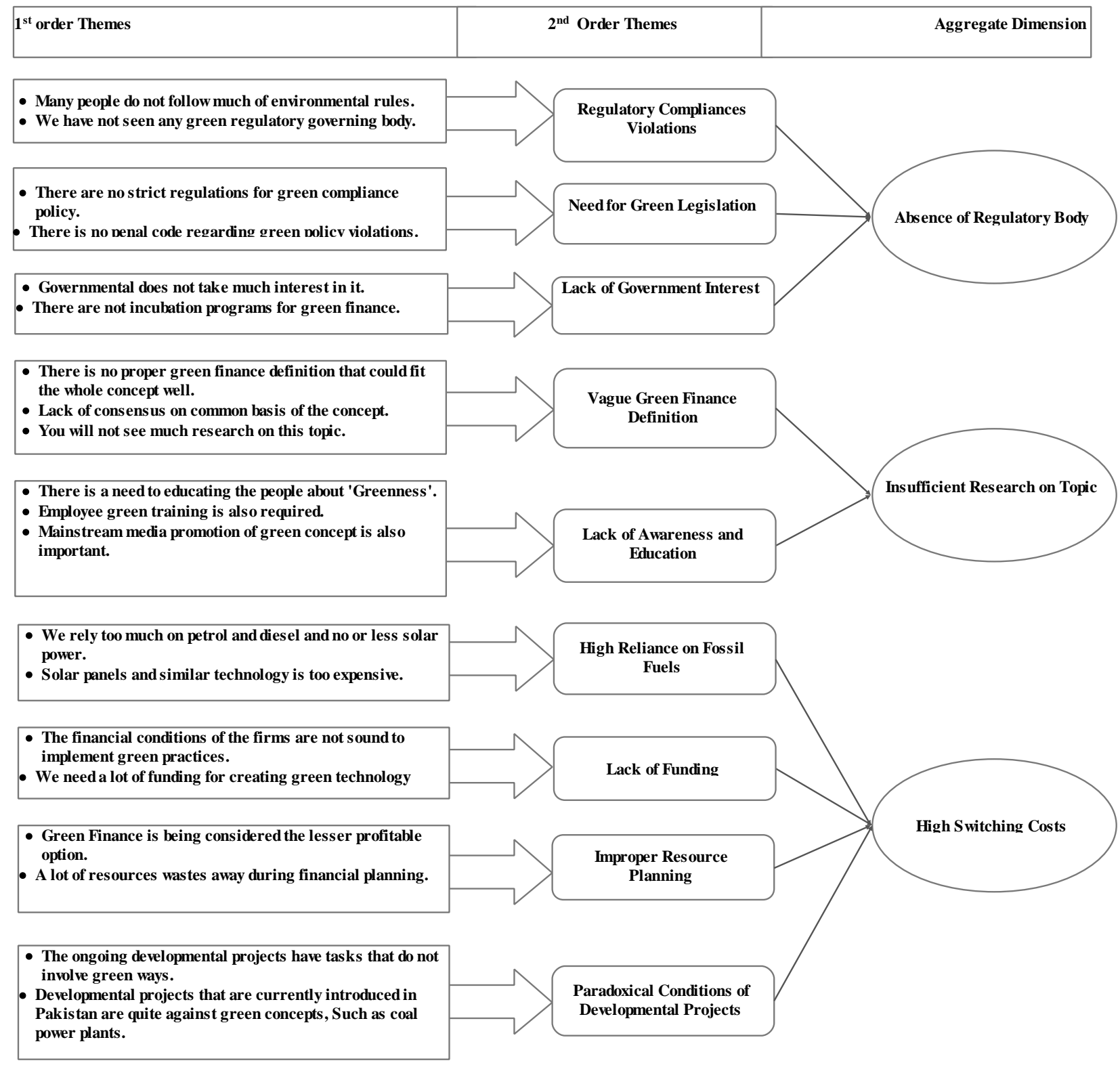

Figure 4. Data Structure of the Interviews

\section{3-2- Interpretive Structural Modelling}

ISM is a vigorous technique for investigating and developing the relationships between various identified factors to illustrate their combined effect on a specific phenomenon under study [62]. It is a contextual approach based on expert opinion where experts decide whether and how the individual factors are connected [63]. Its basic objective is to use the experts' experience, technical knowledge, and skills to break down a complex structure into many sub-systems (elements) and, finally, to create a multi-layered structural model, which can be possible by involving a panel of experts in the process. Therefore, we engage a group of fifteen experts in the process of data collection. The targeted experts were selected based on their experience and awareness about the business, financial, economic, and environmental issues. All the study participants occasionally remained part of the academic and social events concerning green finance activities. In total, four participants belonged to the banking industry; four were academicians; three were environmentalists; two were economists, while two were selected from different areas. The profiles of experts (qualification, experience, occupation, expertise in the field) are provided in Appendix I (Table A2).

The experts were provided with a list of barriers and asked to confirm the obstacles to the green finance adoption system. The panel considered two barriers (inadequate analytical capability and training and complexity in technology to support) overlapping, so both were removed from the list (see Table 3). They were also asked to rank the identified barriers by employing the systematic approach of ISM and identifying the contextual relationship between them. Each participant was asked to determine the effect of each extracted barrier on others, including their direction of a relationship. The process would continue until all pair combinations of the obstacles were extracted. The study follows all the steps of the ISM methodology suggested by Makki et al. (2020) [64], reported in Figure 5. 
Table 3. Verification of barriers by experts

\begin{tabular}{|c|c|c|c|c|c|c|c|c|c|c|c|c|c|c|c|c|c|}
\hline \multirow{2}{*}{ Sr. \# } & \multirow{2}{*}{ Barriers } & \multicolumn{15}{|c|}{ Experts } & \multirow{2}{*}{ Sum } \\
\hline & & 1 & 2 & 3 & 4 & 5 & 6 & 7 & 8 & 9 & 10 & 11 & 12 & 13 & 14 & 15 & \\
\hline 1 & Poor communication with external stakeholders & $\mathrm{x}$ & $\mathrm{x}$ & $\mathrm{x}$ & $\sqrt{ }$ & $\sqrt{ }$ & $\sqrt{ }$ & $\sqrt{ }$ & $\sqrt{ }$ & $\sqrt{ }$ & $\sqrt{ }$ & $\mathrm{x}$ & $\mathrm{x}$ & $\mathrm{x}$ & $\sqrt{ }$ & $\sqrt{ }$ & 9 \\
\hline 2 & Lack of employee training & $\sqrt{ }$ & $\sqrt{ }$ & $\mathrm{x}$ & $\mathrm{x}$ & $\mathrm{x}$ & $\sqrt{ }$ & $\sqrt{ }$ & $\mathrm{x}$ & $\sqrt{ }$ & $\sqrt{ }$ & $\mathrm{x}$ & $\sqrt{ }$ & $\sqrt{ }$ & $\sqrt{ }$ & $\sqrt{ }$ & 10 \\
\hline 3 & Political instability & $\sqrt{ }$ & $\sqrt{ }$ & $\sqrt{ }$ & $\sqrt{ }$ & $\sqrt{ }$ & $\sqrt{ }$ & $\sqrt{ }$ & $\sqrt{ }$ & $\sqrt{ }$ & $\sqrt{ }$ & $\sqrt{ }$ & $\sqrt{ }$ & $\mathrm{x}$ & $\sqrt{ }$ & $\sqrt{ }$ & 14 \\
\hline 4 & Inadequate analytical capability and training & $\mathrm{x}$ & $\mathrm{x}$ & $\sqrt{ }$ & $\sqrt{ }$ & $\mathrm{x}$ & $\mathrm{x}$ & $\mathrm{x}$ & $\sqrt{ }$ & $\sqrt{ }$ & $\mathrm{x}$ & $\sqrt{ }$ & $\mathrm{x}$ & $\mathrm{x}$ & $\mathrm{x}$ & $\mathrm{x}$ & 5 \\
\hline 5 & Knowledge about the "Green" concept & $\sqrt{ }$ & $\sqrt{ }$ & $\sqrt{ }$ & $\sqrt{ }$ & $\sqrt{ }$ & $\sqrt{ }$ & $\sqrt{ }$ & $\sqrt{ }$ & $\sqrt{ }$ & $\sqrt{ }$ & $\sqrt{ }$ & $\sqrt{ }$ & $\sqrt{ }$ & $\sqrt{ }$ & $\sqrt{ }$ & 15 \\
\hline 6 & Lack of technical expertise & $\sqrt{ }$ & $\mathrm{x}$ & $\mathrm{x}$ & $\mathrm{x}$ & $\sqrt{ }$ & $\mathrm{x}$ & $\mathrm{x}$ & $\sqrt{ }$ & $\sqrt{ }$ & $\sqrt{ }$ & $\mathrm{x}$ & $\sqrt{ }$ & $\mathrm{x}$ & $\sqrt{ }$ & $\sqrt{ }$ & 8 \\
\hline 7 & Uncertain economic condition. & $\sqrt{ }$ & $\sqrt{ }$ & $\sqrt{ }$ & $\sqrt{ }$ & $\sqrt{ }$ & $\sqrt{ }$ & $\sqrt{ }$ & $\sqrt{ }$ & $\sqrt{ }$ & $\sqrt{ }$ & $\sqrt{ }$ & $\sqrt{ }$ & $\sqrt{ }$ & $\sqrt{ }$ & $\sqrt{ }$ & 15 \\
\hline 8 & Complexity in technology to support & $\sqrt{ }$ & $\mathrm{x}$ & $\mathrm{x}$ & $\mathrm{x}$ & $\mathrm{x}$ & $\sqrt{ }$ & $\mathrm{x}$ & $\sqrt{ }$ & $\mathrm{x}$ & $\sqrt{ }$ & $\mathrm{x}$ & $\mathrm{x}$ & $\mathrm{x}$ & $\sqrt{ }$ & $\sqrt{ }$ & 6 \\
\hline 9 & Lack of provision for government subsidies & $\sqrt{ }$ & $\mathrm{x}$ & $\sqrt{ }$ & $\sqrt{ }$ & $\sqrt{ }$ & $\sqrt{ }$ & $\sqrt{ }$ & $\sqrt{ }$ & $\mathrm{x}$ & $\sqrt{ }$ & $\mathrm{x}$ & $\mathrm{x}$ & $\mathrm{x}$ & $\mathrm{x}$ & $\mathrm{x}$ & 8 \\
\hline 10 & Lack of interest in the banking sector & $\sqrt{ }$ & $\sqrt{ }$ & $\mathrm{x}$ & $\sqrt{ }$ & $\sqrt{ }$ & $\mathrm{x}$ & $\mathrm{x}$ & $\sqrt{ }$ & $\sqrt{ }$ & $\mathrm{x}$ & $\mathrm{x}$ & $\sqrt{ }$ & $\mathrm{x}$ & $\sqrt{ }$ & $\sqrt{ }$ & 9 \\
\hline 11 & Insufficient research on the topic & $\mathrm{x}$ & $\sqrt{ }$ & $\mathrm{x}$ & $\sqrt{ }$ & $\mathrm{x}$ & $\sqrt{ }$ & $\mathrm{x}$ & $\sqrt{ }$ & $\mathrm{x}$ & $\sqrt{ }$ & $\sqrt{ }$ & $\sqrt{ }$ & $\sqrt{ }$ & $\mathrm{x}$ & $\sqrt{ }$ & 9 \\
\hline 12 & Lack of pressure from global organizations & $\sqrt{ }$ & $\sqrt{ }$ & $\mathrm{x}$ & $\mathrm{x}$ & $\sqrt{ }$ & $\sqrt{ }$ & $\sqrt{ }$ & $\sqrt{ }$ & $\mathrm{x}$ & $\sqrt{ }$ & $\sqrt{ }$ & $\sqrt{ }$ & $\mathrm{x}$ & $\mathrm{x}$ & $\mathrm{x}$ & 9 \\
\hline 13 & Lack of private sector involvement & $\sqrt{ }$ & $\sqrt{ }$ & $\mathrm{x}$ & $\sqrt{ }$ & $\mathrm{x}$ & $\mathrm{x}$ & $\sqrt{ }$ & $\sqrt{ }$ & $\sqrt{ }$ & $\mathrm{x}$ & $\sqrt{ }$ & $\sqrt{ }$ & $\sqrt{ }$ & $\sqrt{ }$ & $\sqrt{ }$ & 11 \\
\hline 14 & Absence of regulatory body & $\sqrt{ }$ & $\sqrt{ }$ & $\mathrm{x}$ & $\sqrt{ }$ & $\sqrt{ }$ & $\sqrt{ }$ & $\mathrm{x}$ & $\mathrm{x}$ & $\mathrm{x}$ & $\mathrm{x}$ & $\sqrt{ }$ & $\sqrt{ }$ & $\sqrt{ }$ & $\sqrt{ }$ & $\sqrt{ }$ & 10 \\
\hline 15 & High switching cost & $\sqrt{ }$ & $\sqrt{ }$ & $\sqrt{ }$ & $\sqrt{ }$ & $\sqrt{ }$ & $\sqrt{ }$ & $\sqrt{ }$ & $\sqrt{ }$ & $\sqrt{ }$ & $\sqrt{ }$ & $\sqrt{ }$ & $\sqrt{ }$ & $\sqrt{ }$ & $\sqrt{ }$ & $\sqrt{ }$ & 15 \\
\hline 16 & Insufficient existing technological structure & $\sqrt{ }$ & $\sqrt{ }$ & $\sqrt{ }$ & $\mathrm{x}$ & $\sqrt{ }$ & $\sqrt{ }$ & $\sqrt{ }$ & $\sqrt{ }$ & $\sqrt{ }$ & $\sqrt{ }$ & $\sqrt{ }$ & $\sqrt{ }$ & $\sqrt{ }$ & $\sqrt{ }$ & $\sqrt{ }$ & 14 \\
\hline 17 & Lack of globally available green criterion & $\sqrt{ }$ & $\sqrt{ }$ & $\mathrm{x}$ & $\mathrm{x}$ & $\mathrm{x}$ & $\sqrt{ }$ & $\mathrm{x}$ & $\mathrm{x}$ & $\sqrt{ }$ & $\sqrt{ }$ & $\sqrt{ }$ & $\mathrm{x}$ & $\sqrt{ }$ & $\sqrt{ }$ & $\sqrt{ }$ & 9 \\
\hline 18 & Risk and process issues & $\sqrt{ }$ & $\sqrt{ }$ & $\sqrt{ }$ & $\mathrm{x}$ & $\sqrt{ }$ & $\mathrm{x}$ & $\mathrm{x}$ & $\mathrm{x}$ & $\sqrt{ }$ & $\mathrm{x}$ & $\sqrt{ }$ & $\mathrm{x}$ & $\sqrt{ }$ & $\mathrm{x}$ & $\sqrt{ }$ & 8 \\
\hline 19 & $\begin{array}{l}\text { Low return on investment as compared to the } \\
\text { cost of green innovations }\end{array}$ & $\mathrm{x}$ & $\sqrt{ }$ & $\mathrm{x}$ & $\mathrm{x}$ & $\sqrt{ }$ & $\sqrt{ }$ & $\mathrm{x}$ & $\mathrm{x}$ & $\sqrt{ }$ & $\sqrt{ }$ & $\mathrm{x}$ & $\sqrt{ }$ & $\sqrt{ }$ & $\sqrt{ }$ & $\sqrt{ }$ & 9 \\
\hline 20 & Unsupportive organizational structure & $\sqrt{ }$ & $\sqrt{ }$ & $\sqrt{ }$ & $\sqrt{ }$ & $\sqrt{ }$ & $\mathrm{x}$ & $\sqrt{ }$ & $\sqrt{ }$ & $\mathrm{x}$ & $\sqrt{ }$ & $\sqrt{ }$ & $\sqrt{ }$ & $\sqrt{ }$ & $\mathrm{x}$ & $\mathrm{x}$ & 11 \\
\hline
\end{tabular}

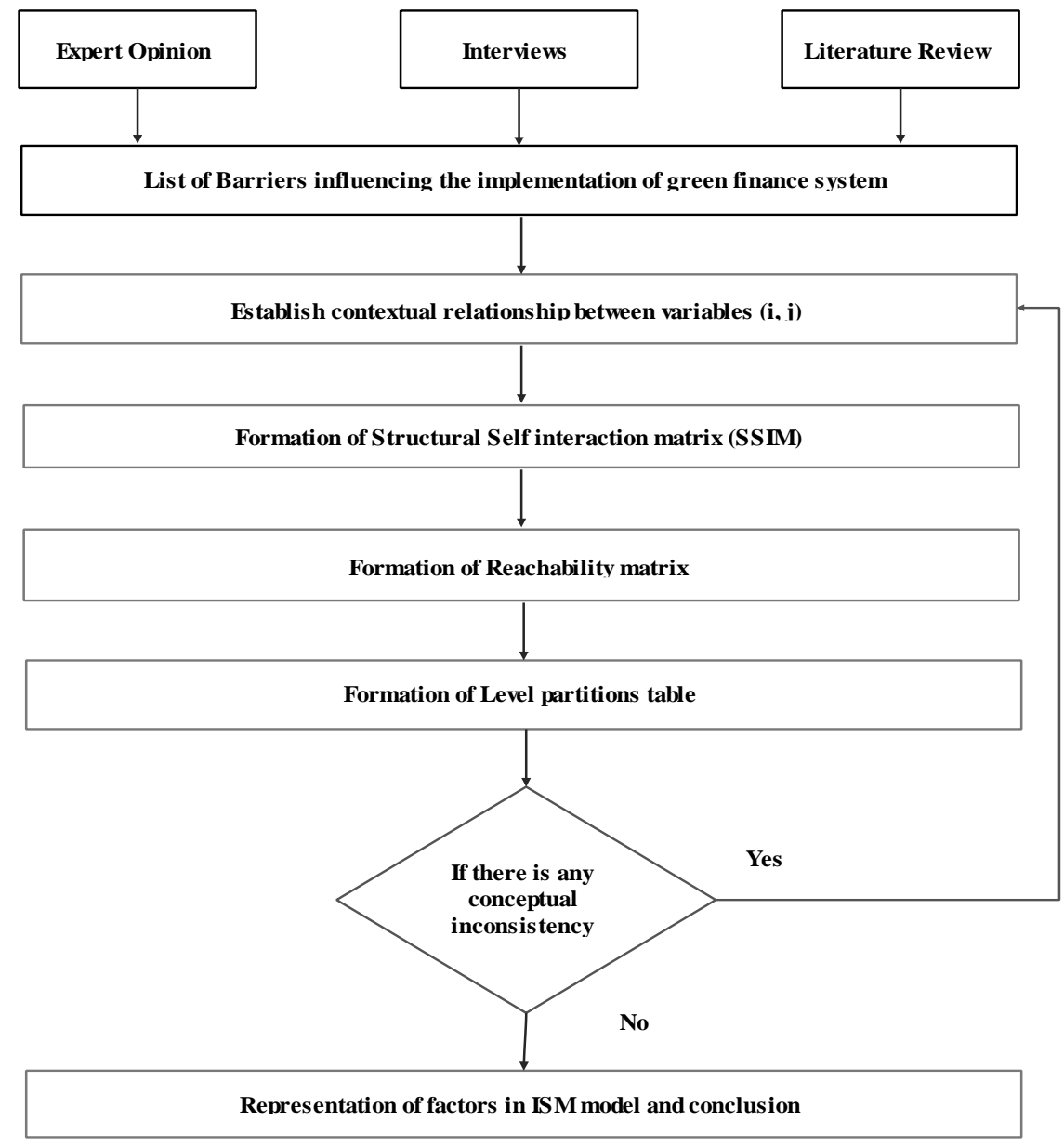

Figure 5. Steps of ISM Methodology 


\section{4- Results}

The current study analyses green finance barriers after identifying and listing them through extensive literature review, interviews and expert opinion. These identified drivers are further processed to discover their interrelationships through the construction of SSIM, which is the first step of the ISM approach [65]. Table 4 for SSIM presents eighteen drivers and their relationships, divided into two types of drivers $(\mathrm{w}, \mathrm{z})$ for providing a simple logical explanation of the relationships. It determines the contextual relationship among the identified obstacles by using the following symbols:

- V: if barrier ' $w$ ' influences to barrier ' $\mathrm{z}$ '

- A: if barrier ' $z$ ' leads to barrier 'w'.

- X: If there is a relation between both the barriers ' $w$ ' and ' $z$ ' and both influences each other.

- O: If barrier ' $w$ ' is not related to barrier ' $z$ '.

For example, the first column represents the relationship of "Poor communication with external stakeholders" with other green finance adoption system impediments. According to the defined rules, here ' $\mathrm{V}$ ' expresses that "Poor communication with external stakeholders" influences to lack of employee training, knowledge about the "Green" concept, lack of technical expertise, uncertain economic condition, lack of provision for government subsidies, lack of interest in the banking sector, lack of pressure from global organizations, insufficient existing technological structure, lack of globally available green criterion, and unsupportive organizational structure symbol 'A' shows that the barriers (high switching cost and low return on investment as compared to the cost of green innovations) lead to the barrier "Poor communication with external stakeholders".

The symbol ' $\mathrm{X}$ ' means there is a relation between the barrier "Poor communication with external stakeholders" and other barriers (insufficient research on the topic, lack of private sector involvement, and absence of regulatory body), and both influence each other. Finally, the symbol ' $\mathrm{O}$ ' indicates that the "Poor communication with external stakeholders" is not related to barriers (political instability and risk and process issues). Similarly, we mention the symbols for other barriers in Table 4 based on the stated rule of defining relationships between them. Then, we develop a Structural Self-Interaction Matrix (SSIM), which depicts the pair-wise contextual relationship among the identified barriers, presented in Table 4.

The next step in ISM modelling is to construct the Initial Reachability Matrix (IRM) for SSIM, which was developed by using the following replacement rules:

- When the given input (w,z) is 'V' in SSIM, (w,z) input in the IRM will be '1', and input (z,w) will be '0'.

- When the given input (w,z) is 'A' in the SSIM, (w,z) input in the IRM will be '0', and input (z,w) will be '1'.

- When the given input (w,z) is ' $\mathrm{X}$ ' in the SSIM, (w,z) input in the IRM will be '1', and input (z,w) will be '1'.

- When the given input (w,z) is 'O' in the SSIM, (w,z) input in the IRM will be ' 0 ', and input $(\mathrm{z}, \mathrm{w})$ will be ' 0 '.

Table 4. Structural self-interaction matrix

\begin{tabular}{|c|c|c|c|c|c|c|c|c|c|c|c|c|c|c|c|c|c|c|}
\hline Sr. \# & Barriers & 1 & 2 & 3 & 4 & 5 & 6 & 7 & 8 & 9 & 10 & 11 & 12 & 13 & 14 & 15 & 16 & 17 \\
\hline 1 & $\begin{array}{l}\text { Poor communication with external } \\
\text { stakeholders }\end{array}$ & & & & & & & & & & & & & & & & & \\
\hline 2 & Lack of employee training & $\mathrm{V}$ & & & & & & & & & & & & & & & & \\
\hline 3 & Political instability & $\mathrm{O}$ & $\mathrm{O}$ & & & & & & & & & & & & & & & \\
\hline 4 & Knowledge about the "Green" concept & $\mathrm{V}$ & A & $\mathrm{V}$ & & & & & & & & & & & & & & \\
\hline 5 & Lack of technical expertise & $\mathrm{V}$ & A & $\mathrm{V}$ & $\mathrm{V}$ & & & & & & & & & & & & & \\
\hline 6 & Uncertain economic condition & $\mathrm{V}$ & $\mathrm{O}$ & $\mathrm{V}$ & A & $\mathrm{X}$ & & & & & & & & & & & & \\
\hline 7 & Lack of provision for government subsidies & $\mathrm{V}$ & $\mathrm{V}$ & A & A & A & A & & & & & & & & & & & \\
\hline 8 & Lack of interest in the banking sector & $\mathrm{V}$ & A & $\mathrm{V}$ & $\mathrm{X}$ & A & $\mathrm{V}$ & A & & & & & & & & & & \\
\hline 9 & Insufficient research on the topic & $\mathrm{X}$ & $\mathrm{V}$ & $\mathrm{V}$ & $\mathrm{V}$ & $\mathrm{X}$ & $\mathrm{X}$ & $\mathrm{X}$ & A & & & & & & & & & \\
\hline 10 & Lack of pressure from global organizations & $\mathrm{V}$ & $\mathrm{V}$ & $\mathrm{V}$ & $\mathrm{V}$ & $\mathrm{V}$ & $\mathrm{V}$ & $\mathrm{X}$ & A & A & & & & & & & & \\
\hline 11 & Lack of private sector involvement & $\mathrm{X}$ & $\mathrm{V}$ & $\mathrm{V}$ & $\mathrm{V}$ & $\mathrm{V}$ & $\mathrm{V}$ & $\mathrm{V}$ & $\mathrm{X}$ & A & A & & & & & & & \\
\hline 12 & Absence of regulatory body & $\mathrm{X}$ & $\mathrm{V}$ & $\mathrm{V}$ & $\mathrm{V}$ & A & A & A & A & A & A & A & & & & & & \\
\hline 13 & High switching cost & A & $\mathrm{V}$ & $\mathrm{O}$ & $\mathrm{V}$ & $\mathrm{V}$ & $X$ & A & V & $\mathrm{V}$ & A & A & $\mathrm{X}$ & & & & & \\
\hline 14 & Insufficient existing technological structure & $\mathrm{V}$ & A & A & $\mathrm{X}$ & A & A & $\mathrm{V}$ & $\mathrm{V}$ & $\mathrm{V}$ & A & $\mathrm{X}$ & A & $\mathrm{O}$ & & & & \\
\hline 15 & Lack of globally available green criterion & $\mathrm{V}$ & $\mathrm{O}$ & $\mathrm{V}$ & $\mathrm{V}$ & $\mathrm{O}$ & $\mathrm{V}$ & $\mathrm{X}$ & $\mathrm{O}$ & A & A & $\mathrm{X}$ & $\mathrm{O}$ & $\mathrm{O}$ & $\mathrm{V}$ & & & \\
\hline 16 & Risk and process issues & $\mathrm{O}$ & $\mathrm{V}$ & $\mathrm{X}$ & $\mathrm{V}$ & $\mathrm{O}$ & A & $\mathrm{V}$ & $\mathrm{V}$ & $\mathrm{V}$ & $\mathrm{V}$ & $\mathrm{V}$ & $\mathrm{O}$ & $\mathrm{V}$ & $\mathrm{O}$ & $\mathrm{O}$ & & \\
\hline 17 & $\begin{array}{l}\text { Low return on investment as compared to } \\
\text { the cost of green innovations }\end{array}$ & A & A & A & $\mathrm{V}$ & $\mathrm{X}$ & $\mathrm{V}$ & $\mathrm{X}$ & $\mathrm{X}$ & A & A & A & A & $\mathrm{O}$ & $\mathrm{O}$ & $\mathrm{O}$ & $\mathrm{O}$ & \\
\hline 18 & Unsupportive organizational structure & V & $\mathrm{V}$ & A & A & A & A & A & A & A & A & A & A & $\mathrm{O}$ & $\mathrm{O}$ & $\mathrm{O}$ & $\mathrm{O}$ & $\mathrm{O}$ \\
\hline
\end{tabular}


For example, the replacement rules to construct IRM for SSIM for the first barrier of green finance adoption system "Poor communication with external stakeholders" are: we replace ' 1 ', if the given input of the barriers are 'V' in SSIM e.g., (poor communication with external stakeholders, lack of employee training) and mention ' 0 ' for input (lack of employee training, poor communication with external stakeholders). When the given input (poor communication with external stakeholders, high switching cost) is 'A' in the SSIM (poor communication with external stakeholders, high switching cost), input in the IRM will be ' 0 ', and input (high switching cost, poor communication with external stakeholders) will be '1'. When the given input (poor communication with external stakeholders, insufficient research on the topic) is ' $\mathrm{X}$ ' in the SSIM (poor communication with external stakeholders, insufficient research on the topic) input in the IRM will be '1', and input (insufficient research on the topic, poor communication with external stakeholders) will be '1'. Similarly, when the given input (poor communication with external stakeholders, political instability) is 'O' in the SSIM, (poor communication with external stakeholders, political instability), input in the IRM will be ' 0 ', and input (political instability, poor communication with external stakeholders) will be ' 0 '. Similarly, the values ' 1 ' and ' 0 ' are assigned for other barriers to explain their relationship with each other by following the defined replacement rule of ISM [66].

Table 5 shows the IRM results for converted values that lead to developing the Final Reachability Matrix (FRM). FRM is based on a transitivity test applied to IRM, where the symbol (*) is used to fill the gap by inference [66]. For example, if barrier ' $\mathrm{X}$ ' is related to barrier ' $\mathrm{Y}$ '; and barrier ' $\mathrm{Y}$ ' is related to barrier ' $\mathrm{Z}$ '; consequently, barrier ' $\mathrm{X}$ ' is also related to barrier ' $Z$ '. Accordingly, ' 0 ' and '1' entries can be verified, and the resulting matrix can be considered as FRM. The findings of FRM are reported in Table 6. The driving and dependence power for the barriers are calculated after finalizing their relationship through accounting transitivity. The driving power of a factor is the total number of the first column, while dependence power is based on the total number of the first row. Both of them help to classify the barriers into four clusters: dependent, autonomous, linkages and independent [67]. Dependent explains a weak driving power but strong dependent power. Any action taken on such barriers can affect others as well as reciprocate the effect on themselves. Autonomous reflects weak driving and dependent power. It indicates that the factors are disconnected from the system. Linkage represents a strong driving and dependent power, which means that elements are unstable, and any action taken on such barriers can affect others as well as reciprocate the effect on themselves. Independent presents a strong driving power but weak, dependent power. MICMAC cross-impact matrix multiplication applied to classification) analysis for classification of barriers based on their driving and dependence power is shown in Figure 6.

Table 5. Initial reachability matrix

\begin{tabular}{|c|c|c|c|c|c|c|c|c|c|c|c|c|c|c|c|c|c|c|}
\hline Barriers & 1 & 2 & 3 & 4 & 5 & 6 & 7 & 8 & 9 & 10 & 11 & 12 & 13 & 14 & 15 & 16 & 17 & 18 \\
\hline 1 & 1 & 0 & 0 & 0 & 0 & 0 & 0 & 0 & 1 & 0 & 1 & 1 & 1 & 0 & 0 & 0 & 1 & 0 \\
\hline 2 & 1 & 1 & 0 & 1 & 1 & 0 & 0 & 1 & 0 & 0 & 0 & 0 & 0 & 1 & 0 & 0 & 1 & 0 \\
\hline 3 & 0 & 0 & 1 & 0 & 0 & 0 & 1 & 0 & 0 & 0 & 0 & 0 & 0 & 1 & 0 & 1 & 1 & 1 \\
\hline 4 & 1 & 0 & 1 & 1 & 0 & 1 & 1 & 1 & 0 & 0 & 0 & 0 & 0 & 1 & 0 & 0 & 0 & 1 \\
\hline 5 & 1 & 0 & 1 & 1 & 1 & 1 & 1 & 1 & 1 & 0 & 0 & 0 & 0 & 1 & 0 & 0 & 1 & 1 \\
\hline 6 & 1 & 0 & 1 & 0 & 1 & 1 & 1 & 0 & 1 & 0 & 0 & 0 & 1 & 1 & 0 & 1 & 0 & 1 \\
\hline 7 & 1 & 1 & 0 & 0 & 0 & 0 & 1 & 1 & 1 & 1 & 0 & 0 & 1 & 0 & 1 & 0 & 1 & 1 \\
\hline 8 & 1 & 0 & 1 & 1 & 0 & 1 & 0 & 1 & 1 & 1 & 1 & 0 & 0 & 0 & 0 & 0 & 1 & 1 \\
\hline 9 & 1 & 1 & 1 & 1 & 1 & 1 & 1 & 0 & 1 & 1 & 1 & 1 & 0 & 0 & 1 & 0 & 1 & 1 \\
\hline 10 & 1 & 1 & 1 & 1 & 1 & 1 & 1 & 0 & 0 & 1 & 1 & 1 & 1 & 1 & 1 & 0 & 1 & 1 \\
\hline 11 & 1 & 1 & 1 & 1 & 1 & 1 & 1 & 1 & 0 & 0 & 1 & 1 & 1 & 1 & 1 & 0 & 1 & 1 \\
\hline 12 & 1 & 1 & 1 & 1 & 0 & 0 & 0 & 0 & 0 & 0 & 0 & 1 & 1 & 1 & 0 & 0 & 1 & 1 \\
\hline 13 & 0 & 1 & 0 & 1 & 1 & 1 & 0 & 1 & 1 & 0 & 0 & 1 & 1 & 0 & 0 & 0 & 0 & 0 \\
\hline 14 & 1 & 0 & 0 & 1 & 0 & 0 & 1 & 1 & 1 & 0 & 1 & 0 & 0 & 1 & 0 & 0 & 0 & 0 \\
\hline 15 & 1 & 0 & 1 & 1 & 0 & 1 & 1 & 0 & 0 & 0 & 1 & 0 & 0 & 1 & 1 & 0 & 0 & 0 \\
\hline 16 & 0 & 1 & 1 & 1 & 0 & 0 & 1 & 1 & 1 & 1 & 1 & 0 & 1 & 0 & 0 & 1 & 0 & 0 \\
\hline 17 & 0 & 0 & 0 & 1 & 1 & 1 & 1 & 1 & 0 & 0 & 0 & 0 & 0 & 0 & 0 & 0 & 1 & 0 \\
\hline 18 & 1 & 1 & 0 & 0 & 0 & 0 & 0 & 0 & 0 & 0 & 0 & 0 & 0 & 0 & 0 & 0 & 0 & 1 \\
\hline
\end{tabular}


Table 6. Final reachability matrix

\begin{tabular}{|c|c|c|c|c|c|c|c|c|c|c|c|c|c|c|c|c|c|c|c|}
\hline Barriers & 1 & 2 & 3 & 4 & 5 & 6 & 7 & 8 & 9 & 10 & 11 & 12 & 13 & 14 & 15 & 16 & 17 & 18 & Driving Power \\
\hline 1 & 1 & $1 *$ & $1 *$ & $1 *$ & $1 *$ & $1 *$ & $1 *$ & $1 *$ & 1 & $1 *$ & 1 & 1 & 1 & $1 *$ & $1 *$ & 0 & 1 & $1 *$ & 17 \\
\hline 2 & 1 & 1 & $1^{*}$ & 1 & 1 & $1^{*}$ & $1^{*}$ & 1 & $1^{*}$ & $1^{*}$ & $1 *$ & $1^{*}$ & $1^{*}$ & 1 & 0 & 0 & 1 & $1^{*}$ & 16 \\
\hline 3 & $1 *$ & $1 *$ & 1 & $1 *$ & $1^{*}$ & $1 *$ & 1 & $1 *$ & $1^{*}$ & $1 *$ & $1 *$ & $1 *$ & $1 *$ & 1 & $1 *$ & 1 & 1 & 1 & 18 \\
\hline 4 & 1 & $1 *$ & 1 & 1 & $1^{*}$ & 1 & 1 & 1 & $1^{*}$ & $1^{*}$ & $1 *$ & $1^{*}$ & $1^{*}$ & 1 & $1^{*}$ & $1^{*}$ & $1^{*}$ & 1 & 18 \\
\hline 5 & 1 & $1 *$ & 1 & 1 & 1 & 1 & 1 & 1 & 1 & $1 *$ & $1 *$ & $1 *$ & $1 *$ & 1 & $1 *$ & $1 *$ & 1 & 1 & 18 \\
\hline 6 & 1 & $1^{*}$ & 1 & $1^{*}$ & 1 & 1 & 1 & $1^{*}$ & 1 & $1^{*}$ & $1^{*}$ & $1^{*}$ & 1 & 1 & $1^{*}$ & 1 & $1^{*}$ & 1 & 18 \\
\hline 7 & 1 & 1 & $1^{*}$ & $1^{*}$ & $1^{*}$ & $1 *$ & 1 & 1 & 1 & 1 & $1^{*}$ & $1^{*}$ & 1 & $1^{*}$ & 1 & 0 & 1 & 1 & 17 \\
\hline 8 & 1 & $1 *$ & 1 & 1 & $1 *$ & 1 & $1^{*}$ & 1 & 1 & 1 & 1 & $1 *$ & $1 *$ & $1^{*}$ & $1^{*}$ & $1^{*}$ & 1 & 1 & 18 \\
\hline 9 & 1 & 1 & 1 & 1 & 1 & 1 & 1 & $1 *$ & 1 & 1 & 1 & 1 & $1 *$ & $1^{*}$ & 1 & $1^{*}$ & 1 & 1 & 18 \\
\hline 10 & 1 & 1 & 1 & 1 & 1 & 1 & 1 & $1^{*}$ & $1^{*}$ & 1 & 1 & 1 & 1 & 1 & 1 & $1^{*}$ & 1 & 1 & 18 \\
\hline 11 & 1 & 1 & 1 & 1 & 1 & 1 & 1 & 1 & $1^{*}$ & $1^{*}$ & 1 & 1 & 1 & 1 & 1 & $1^{*}$ & 1 & 1 & 18 \\
\hline 12 & 1 & 1 & 1 & 1 & $1 *$ & $1 *$ & $1^{*}$ & $1 *$ & $1^{*}$ & 0 & $1 *$ & 1 & 1 & 1 & 0 & $1^{*}$ & 1 & 1 & 16 \\
\hline 13 & $1 *$ & 1 & $1 *$ & 1 & 1 & 1 & $1^{*}$ & 1 & 1 & $1 *$ & $1 *$ & 1 & 1 & $1^{*}$ & $1^{*}$ & $1^{*}$ & $1 *$ & $1^{*}$ & 18 \\
\hline 14 & 1 & $1 *$ & $1^{*}$ & 1 & $1^{*}$ & $1^{*}$ & 1 & 1 & 1 & $1^{*}$ & 1 & $1^{*}$ & $1^{*}$ & 1 & $1^{*}$ & 0 & $1^{*}$ & $1^{*}$ & 17 \\
\hline 15 & 1 & $1^{*}$ & 1 & 1 & $1^{*}$ & 1 & 1 & $1^{*}$ & $1^{*}$ & $1^{*}$ & 1 & $1^{*}$ & $1^{*}$ & 1 & 1 & $1^{*}$ & $1^{*}$ & $1^{*}$ & 18 \\
\hline 16 & $1^{*}$ & 1 & 1 & 1 & $1^{*}$ & $1^{*}$ & 1 & 1 & 1 & 1 & 1 & $1^{*}$ & 1 & $1^{*}$ & $1^{*}$ & 1 & $1^{*}$ & $1^{*}$ & 18 \\
\hline 17 & $1 *$ & $1 *$ & $1^{*}$ & 1 & 1 & 1 & 1 & 1 & $1^{*}$ & $1 *$ & $1 *$ & 0 & $1^{*}$ & $1^{*}$ & $1^{*}$ & $1^{*}$ & 1 & $1^{*}$ & 17 \\
\hline 18 & 1 & 1 & 0 & $1^{*}$ & $1^{*}$ & 0 & 0 & $1^{*}$ & $1^{*}$ & 0 & $1 *$ & $1^{*}$ & $1^{*}$ & $1^{*}$ & $1^{*}$ & 0 & $1^{*}$ & 1 & 13 \\
\hline dence Power & 18 & 18 & 17 & 18 & 18 & 17 & 17 & 18 & 18 & 16 & 18 & 17 & 18 & 18 & 16 & 13 & 18 & 18 & \\
\hline
\end{tabular}

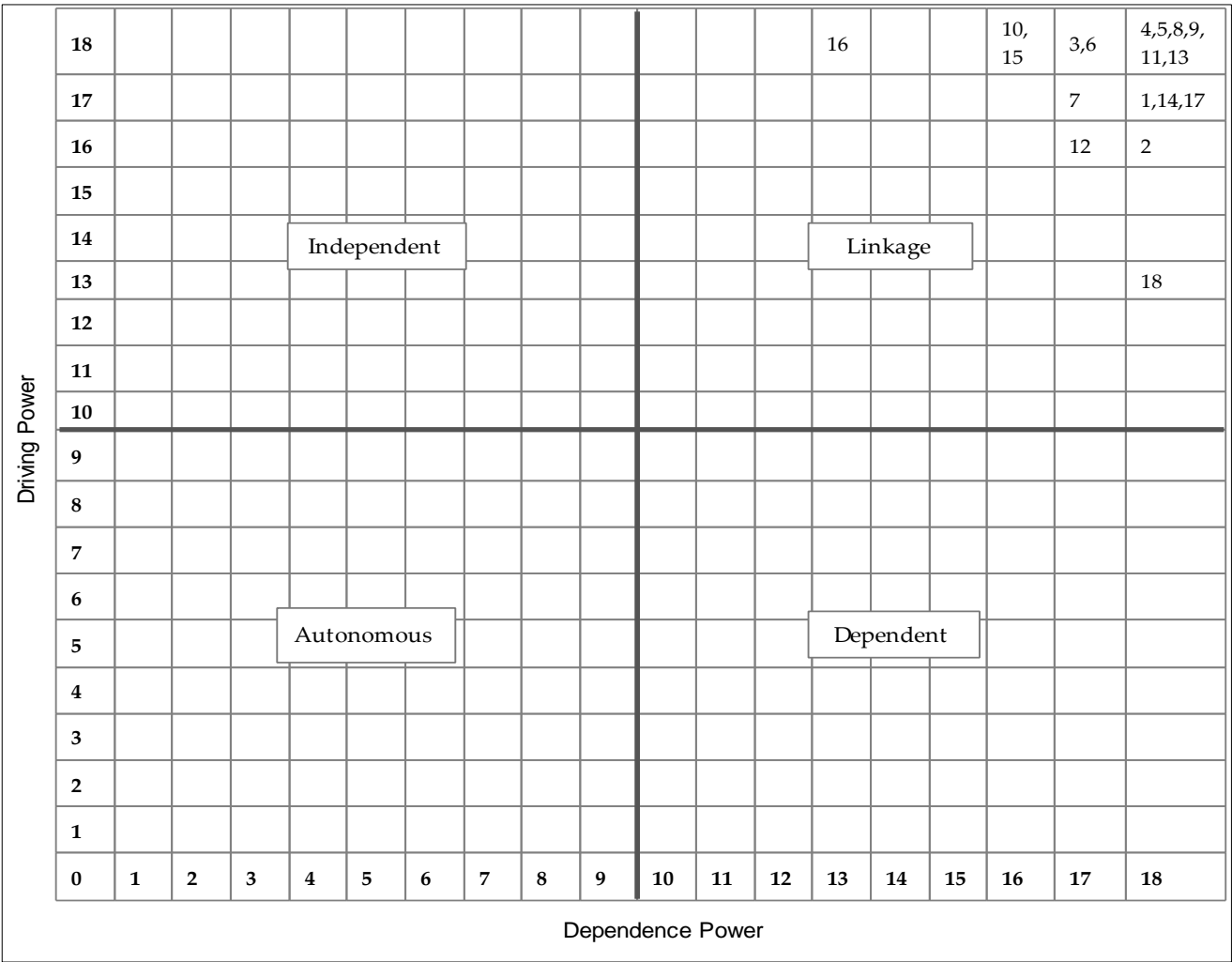

Figure 6. MICMAC Analysis

Figure 6 clearly shows that no barrier falls in independent, autonomous, and dependent clusters. All the factors lie under linkage clusters that indicate their strong driving and dependence power. It further shows that all the factors are interlinked and unstable as any action taken on them can influence others and also have a feedback effect on themselves [68]. In the next step, we obtain the reachability and antecedent set from FRM for each identified barrier that defines their level based on intersection sets. Reachability set comprises of a set of elements, including itself and others, which causes an impact. In contrast, an antecedent set is based on the set of elements, including itself and others that affect the 
primary variable. The barriers that are similar in the reachability and antecedent sets are reported in the interaction set. The hierarchy in ISM is determined by the level of similarity in reachability and intersection sets, shown in Table 7. We have identified twelve barriers at level I, four at level II, and two at level III.

Table 7. Summary of iterations

\begin{tabular}{|c|c|c|c|c|}
\hline Barriers & Reachability Set & Antecedent Set & Interaction Set & Level \\
\hline \multicolumn{5}{|c|}{ Iteration I } \\
\hline 1 & $1,2,3,4,5,6,7,8,9,10,11,12,13,14,15,17,18$ & $1,2,3,4,5,6,7,8,9,10,11,12,13,14,15,16,17,18$ & $1,2,3,4,5,6,7,8,9,10,11,12,13,14,15,17,18$ & $I$ \\
\hline 2 & $1,2,3,4,5,6,7,8,9,10,11,12,13,14,17,18$ & $1,2,3,4,5,6,7,8,9,10,11,12,13,14,15,16,17,18$ & $1,2,3,4,5,6,7,8,9,10,11,12,13,14,17,18$ & $I$ \\
\hline 3 & $1,2,3,4,5,6,7,8,9,10,11,12,13,14,15,16,17,18$ & $1,2,3,4,5,6,7,8,9,10,11,12,13,14,15,16,17$ & $1,2,3,4,5,6,7,8,9,10,11,12,13,14,15,16,17$ & \\
\hline 4 & $1,2,3,4,5,6,7,8,9,10,11,12,13,14,15,16,17,18$ & $1,2,3,4,5,6,7,8,9,10,11,12,13,14,15,16,17,18$ & $1,2,3,4,5,6,7,8,9,10,11,12,13,14,15,16,17,18$ & $I$ \\
\hline 5 & $1,2,3,4,5,6,7,8,9,10,11,12,13,14,15,16,17,18$ & $1,2,3,4,5,6,7,8,9,10,11,12,13,14,15,16,17,18$ & $1,2,3,4,5,6,7,8,9,10,11,12,13,14,15,16,17,18$ & $I$ \\
\hline 6 & $1,2,3,4,5,6,7,8,9,10,11,12,13,14,15,16,17,18$ & $1,2,3,4,5,6,7,8,9,10,11,12,13,14,15,16,17$ & $1,2,3,4,5,6,7,8,9,10,11,12,13,14,15,16,17$ & \\
\hline 7 & $1,2,3,4,5,6,7,8,9,10,11,12,13,14,15,17,18$ & $1,2,3,4,5,6,7,8,9,10,11,12,13,14,15,16,17$ & $1,2,3,4,5,6,7,8,9,10,11,12,13,14,15,17$ & \\
\hline 8 & $1,2,3,4,5,6,7,8,9,10,11,12,13,14,15,16,17,18$ & $1,2,3,4,5,6,7,8,9,10,11,12,13,14,15,16,17,18$ & $1,2,3,4,5,6,7,8,9,10,11,12,13,14,15,16,17,18$ & $I$ \\
\hline 9 & $1,2,3,4,5,6,7,8,9,10,11,12,13,14,15,16,17,18$ & $1,2,3,4,5,6,7,8,9,10,11,12,13,14,15,16,17,18$ & $1,2,3,4,5,6,7,8,9,10,11,12,13,14,15,16,17,18$ & $I$ \\
\hline 10 & $1,2,3,4,5,6,7,8,9,10,11,12,13,14,15,16,17,18$ & $1,2,3,4,5,6,7,8,9,10,11,13,14,15,16,17$ & $1,2,3,4,5,6,7,8,9,10,11,13,14,15,16,17$ & \\
\hline 11 & $1,2,3,4,5,6,7,8,9,10,11,12,13,14,15,16,17,18$ & $1,2,3,4,5,6,7,8,9,10,11,12,13,14,15,16,17,18$ & $1,2,3,4,5,6,7,8,9,10,11,12,13,14,15,16,17,18$ & $I$ \\
\hline 12 & $1,2,3,4,5,6,7,8,9,11,12,13,14,16,17,18$ & $1,2,3,4,5,6,7,8,9,10,11,12,13,14,15,16,18$ & $1,2,3,4,5,6,7,8,9,11,12,13,14,16,18$ & \\
\hline 13 & $1,2,3,4,5,6,7,8,9,10,11,12,13,14,15,16,17,18$ & $1,2,3,4,5,6,7,8,9,10,11,12,13,14,15,16,17,18$ & $1,2,3,4,5,6,7,8,9,10,11,12,13,14,15,16,17,18$ & $I$ \\
\hline 14 & $1,2,3,4,5,6,7,8,9,10,11,12,13,14,15,17,18$ & $1,2,3,4,5,6,7,8,9,10,11,12,13,14,15,16,17,18$ & $1,2,3,4,5,6,7,8,9,10,11,12,13,14,15,17,18$ & $I$ \\
\hline 15 & $1,3,4,5,6,7,8,9,10,11,13,14,15,16,17,18$ & $1,2,3,4,5,6,7,8,9,10,11,12,13,14,15,16,17,18$ & $1,3,4,5,6,7,8,9,10,11,13,14,15,16,17,18$ & \\
\hline 16 & $3,4,5,6,8,9,10,11,12,13,15,16,17$ & $1,2,3,4,5,6,7,8,9,10,11,12,13,14,15,16,17,18$ & $3,4,5,6,8,9,10,11,12,13,15,16,17$ & $I$ \\
\hline 17 & $1,2,3,4,5,6,7,8,9,10,11,13,14,15,16,17,18$ & $1,2,3,4,5,6,7,8,9,10,11,12,13,14,15,16,17,18$ & $1,2,3,4,5,6,7,8,9,10,11,13,14,15,16,17,18$ & $I$ \\
\hline 18 & $1,2,4,5,8,9,11,12,13,14,15,17,18$ & $1,2,3,4,5,6,7,8,9,10,11,12,13,14,15,16,17,18$ & $1,2,4,5,8,9,11,12,13,14,15,17,18$ & $I$ \\
\hline \multicolumn{5}{|c|}{ Iteration II } \\
\hline 3 & $3,6,7,10,12,15$ & $3,6,7,10,12,15$ & $3,6,7,10,12,15$ & II \\
\hline 6 & $3,6,7,10,12,15$ & $3,6,7,10,12,15$ & $3,6,7,10,12,15$ & II \\
\hline 7 & $3,6,7,10,12,15$ & $3,6,7,10,12,15$ & $3,6,7,10,12,15$ & II \\
\hline 10 & $3,6,7,10,12,15$ & $3,6,7,10,15$ & $3,6,7,10,15$ & \\
\hline 12 & $3,6,7,12,15$ & $3,6,7,10,12,15$ & $3,6,7,12,15$ & II \\
\hline 15 & $3,6,7,10,12,15$ & $3,6,7,10,15$ & $3,6,7,10,15$ & \\
\hline \multicolumn{5}{|c|}{ Iteration III } \\
\hline 10 & 10,15 & 10,15 & 10,15 & $I I I$ \\
\hline 15 & 10,15 & 10,15 & 10,15 & III \\
\hline
\end{tabular}

After completing the process of level partitioning, we developed the conical matrix by clustering the barriers achieved at a particular level, reported in Table 8. We separated the barriers attained at different levels of iterations. Barriers 1, 2, $4,5,8,9,11,13,14,16,17,18$ (poor communication with external stakeholders, lack of employee training, knowledge about the "Green" concept, lack of technical expertise, lack of interest in the banking sector, insufficient research on the topic, lack of private sector involvement, high switching cost, insufficient existing technological structure, risk and process issues, low return on investment as compared to the cost of green innovations, unsupportive organizational structure) are found at a level I, barriers 3, 6, 7, 12 (political instability, uncertain economic condition, lack of provision for government subsidies, absence of regulatory body) was elaborated at level II. Barriers 10 and 15 (lack of pressure from global organizations, lack of globally available green criterion) were added at level III. These barriers are prioritized as per FRM into the determined and identified number of levels. 
Table 8. Conical matrix

\begin{tabular}{ccccccccccccccccccc}
\hline Barriers & $\mathbf{1}$ & $\mathbf{2}$ & $\mathbf{4}$ & $\mathbf{5}$ & $\mathbf{8}$ & $\mathbf{9}$ & $\mathbf{1 1}$ & $\mathbf{1 3}$ & $\mathbf{1 4}$ & $\mathbf{1 6}$ & $\mathbf{1 7}$ & $\mathbf{1 8}$ & $\mathbf{3}$ & $\mathbf{6}$ & $\mathbf{7}$ & $\mathbf{1 2}$ & $\mathbf{1 0}$ & $\mathbf{1 5}$ \\
\hline $\mathbf{1}$ & 1 & 1 & 1 & 1 & 1 & 1 & 1 & 1 & 1 & 0 & 1 & 1 & 1 & 1 & 1 & 1 & 1 & 1 \\
$\mathbf{2}$ & 1 & 1 & 1 & 1 & 1 & 1 & 1 & 1 & 1 & 0 & 1 & 1 & 1 & 1 & 1 & 1 & 1 & 0 \\
$\mathbf{4}$ & 1 & 1 & 1 & 1 & 1 & 1 & 1 & 1 & 1 & 1 & 1 & 1 & 1 & 1 & 1 & 1 & 1 & 1 \\
$\mathbf{5}$ & 1 & 1 & 1 & 1 & 1 & 1 & 1 & 1 & 1 & 1 & 1 & 1 & 1 & 1 & 1 & 1 & 1 & 1 \\
$\mathbf{8}$ & 1 & 1 & 1 & 1 & 1 & 1 & 1 & 1 & 1 & 1 & 1 & 1 & 1 & 1 & 1 & 1 & 1 & 1 \\
$\mathbf{9}$ & 1 & 1 & 1 & 1 & 1 & 1 & 1 & 1 & 1 & 1 & 1 & 1 & 1 & 1 & 1 & 1 & 1 & 1 \\
$\mathbf{1 1}$ & 1 & 1 & 1 & 1 & 1 & 1 & 1 & 1 & 1 & 1 & 1 & 1 & 1 & 1 & 1 & 1 & 1 & 1 \\
$\mathbf{1 3}$ & 1 & 1 & 1 & 1 & 1 & 1 & 1 & 1 & 1 & 1 & 1 & 1 & 1 & 1 & 1 & 1 & 1 & 1 \\
$\mathbf{1 4}$ & 1 & 1 & 1 & 1 & 1 & 1 & 1 & 1 & 1 & 0 & 1 & 1 & 1 & 1 & 1 & 1 & 1 & 1 \\
$\mathbf{1 6}$ & 1 & 1 & 1 & 1 & 1 & 1 & 1 & 1 & 1 & 1 & 1 & 1 & 1 & 1 & 1 & 1 & 1 & 1 \\
$\mathbf{1 7}$ & 1 & 1 & 1 & 1 & 1 & 1 & 1 & 1 & 1 & 1 & 1 & 1 & 1 & 1 & 1 & 0 & 1 & 1 \\
$\mathbf{1 8}$ & 1 & 1 & 1 & 1 & 1 & 1 & 1 & 1 & 1 & 0 & 1 & 1 & 0 & 0 & 0 & 1 & 0 & 1 \\
$\mathbf{3}$ & 1 & 1 & 1 & 1 & 1 & 1 & 1 & 1 & 1 & 1 & 1 & 1 & 1 & 1 & 1 & 1 & 1 & 1 \\
$\mathbf{6}$ & 1 & 1 & 1 & 1 & 1 & 1 & 1 & 1 & 1 & 1 & 1 & 1 & 1 & 1 & 1 & 1 & 1 & 1 \\
$\mathbf{7}$ & 1 & 1 & 1 & 1 & 1 & 1 & 1 & 1 & 1 & 0 & 1 & 1 & 1 & 1 & 1 & 1 & 1 & 1 \\
$\mathbf{1 2}$ & 1 & 1 & 1 & 1 & 1 & 1 & 1 & 1 & 1 & 1 & 1 & 1 & 1 & 1 & 1 & 1 & 1 & 0 \\
$\mathbf{1 0}$ & 1 & 1 & 1 & 1 & 1 & 1 & 1 & 1 & 1 & 1 & 1 & 1 & 1 & 1 & 1 & 1 & 1 & 1 \\
$\mathbf{1 5}$ & 1 & 1 & 1 & 1 & 1 & 1 & 1 & 1 & 1 & 1 & 1 & 1 & 1 & 1 & 1 & 1 & 1 & 1 \\
\hline
\end{tabular}

A conical matrix is developed by clustering the identified barriers at the same level of the rows/columns of the final reachability matrix [52]. First, the driving power is determined by adding up the value ' 1 ' in the rows, and dependence power is decided by summing up the value ' 1 ' in the column. Next, the driving and dependence power ranks of a barrier/driver are derived through the maximum occurrence of the value ' 1 ', which represents that the barrier/driver appears maximum times in the rows and columns, consequently. A conical matrix helps to make an initial digraph which is the graphical presentation of the elements (barriers), including transitivity links [69]. It makes a basic model structure that explains the correlation between the identified obstacles through bunching factors in almost the same dimensions over the lines and divides them to the last reachability. Nodes and lines of the edges create it without indirect links and hierarchical levels (see Figure 7).

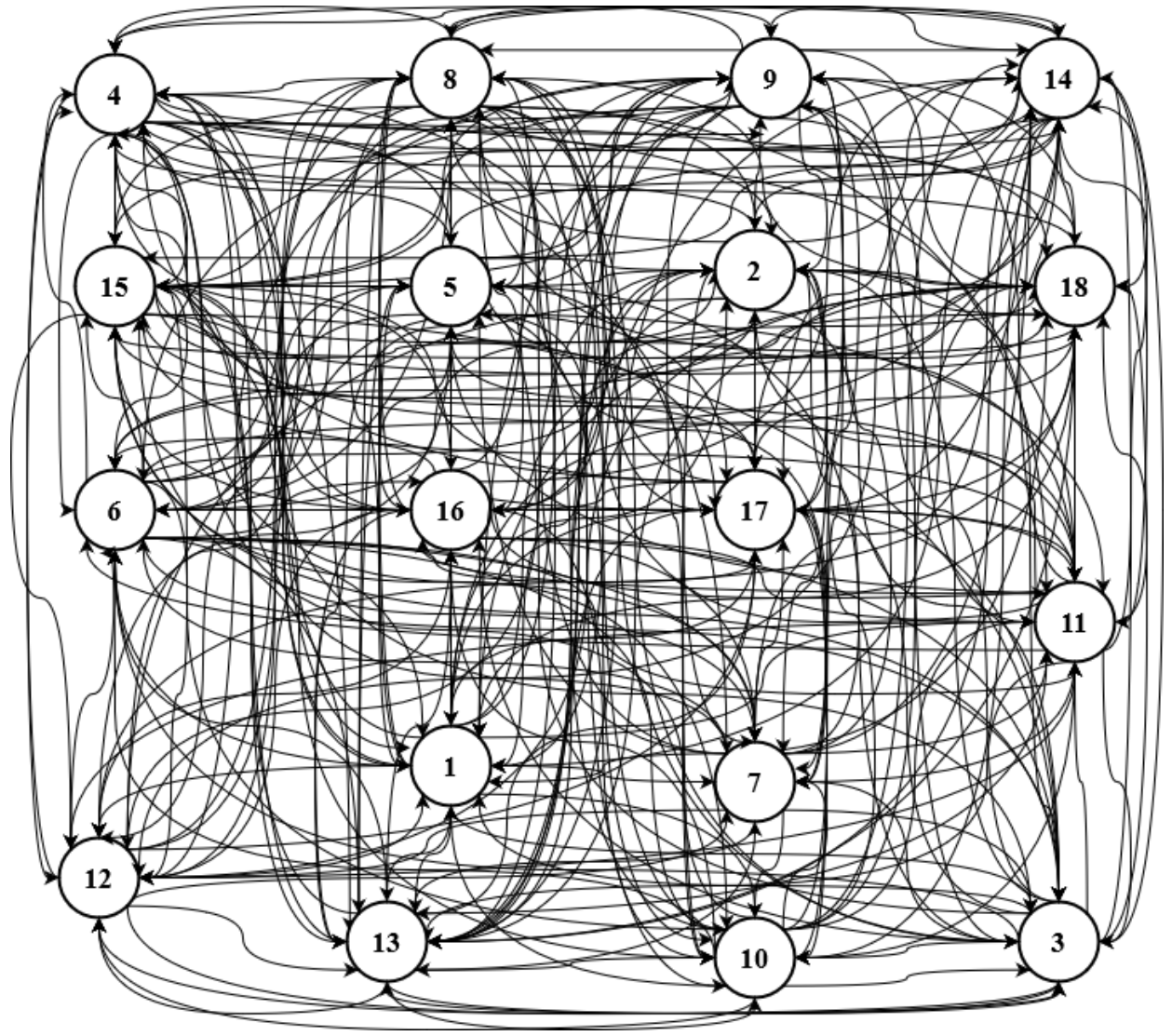

Figure 7. Digraph Presenting Relationship among Green Finance Barriers 
Finally, the resulting digraph is transformed into a final form of the ISM model as there is no issue of transitivity links. Here we replace the variables nodes with the statements iteration of driving forces is determined through their changes in number. The top-to-bottom factor (barrier) position is decided based on the value ' 1 ' that appears maximum times in the row, column, or line [64]. The top-level barriers are positioned at a level I, middle-level barriers are placed at a level II. In contrast, bottom-level barriers are shown at level III of the model. The ISM model presented in figure 8 provides a clear picture of green finance adoption impediments and their flow of relationships. The barriers are divided into three levels that can be further categorized into three broader groups: individual or organizational (level I); country (level II); and global (level III). Figure 8 indicates a need to pay more attention to the bottom-line barriers: lack of pressure from global organizations and lack of globally available green criterion, to implement the sustainable green finance system in Pakistan.

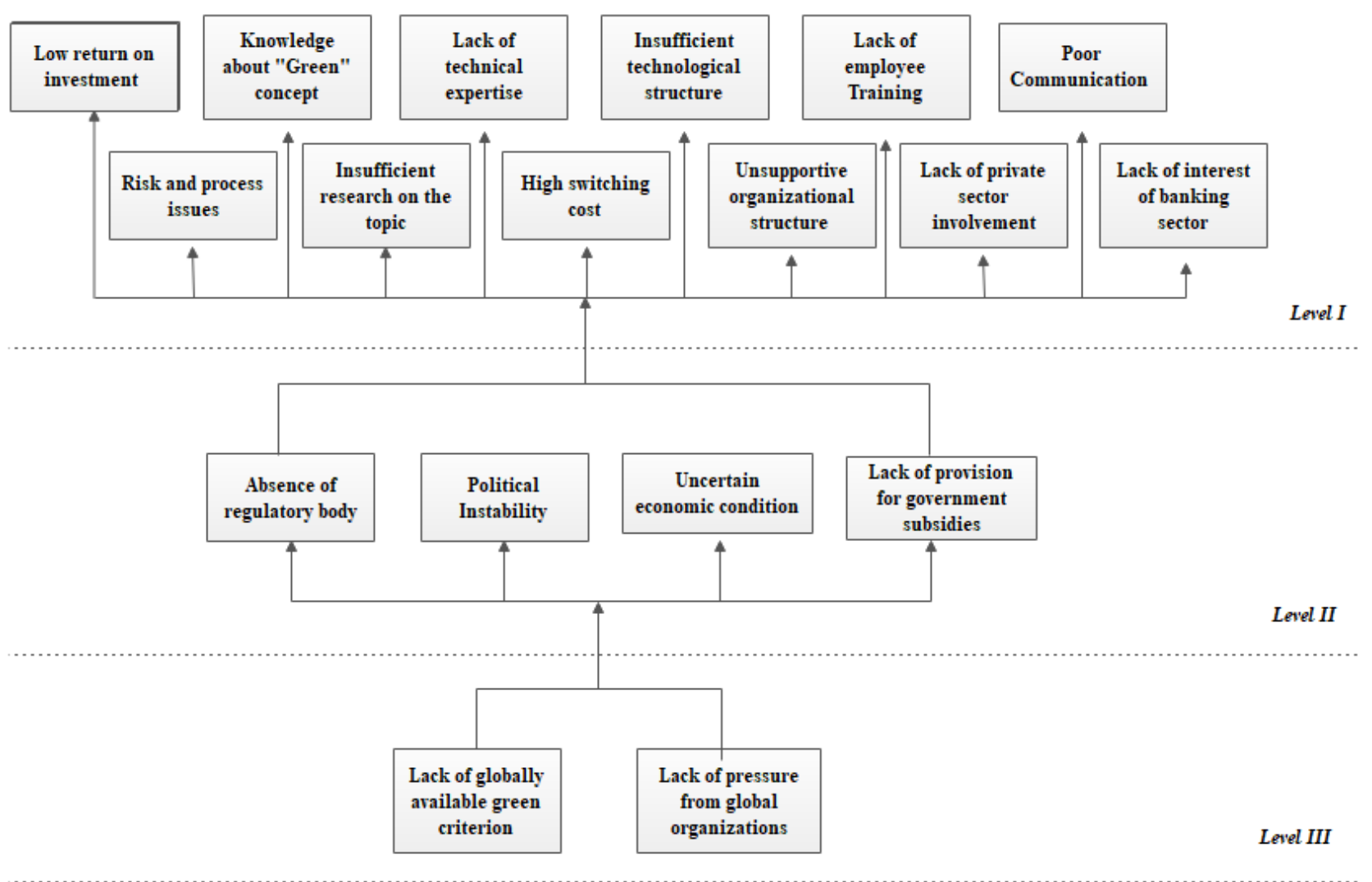

Figure 8. ISM Model for Barriers of Green Finance

\section{5- Discussion}

The unpredictable climate changes have become a severe threat to world economic prosperity and financial stability [70]. All the countries are trying to handle environmental challenges. It extends the severe economic and social issues related to food scarcity, clean water sources, growing disease levels, malnutrition, poverty, etc. [71, 72]. That is why all the countries are encouraging their organizations to adopt sustainable green finance systems to reduce the detrimental effect of climate change on their economies. A sustainable green finance system promotes green practices, low carbon emissions, and renewable energy projects that reduce the adverse impact of climate change. However, this system requires technical expertise, knowledge, and a considerable investment for implementation that developed countries already have but stands as a limitation for the developing countries. The current study is aimed to identify the barriers to the sustainable green finance system in developing countries and how they are related to each other?

The study is conducted in the context of Pakistan. Data were collected in two phases. First, an extensive literature review is conducted to identify the barriers from the prior studies and then combine them with the interview data. The list of barriers included 18 factors finalized by the consensus of panel experts engaged in the ranking process. All the identified barriers are sought based on the opinions of the experts from the field of banking, economics, environmental sciences, and financial managers. ISM technique is used to establish a hierarchical inter-relationship among the identified barriers followed by the formation of clusters using MICMAC analysis. From the MICMAC analysis, it is clear that all the barriers existed in the third quadrant, which is the linkage cluster. These barriers possess a strong dependence and a strong driving power. Barriers in the linkage group are volatile as any change in one of them will affect other barriers as well as causes a change in themselves [62]. Hence, these barriers must be intently considered for rectification by the policymakers [68]. 
The ISM model is prepared after evaluating the transitivity [66]. All eighteen identified barriers to the green finance adoption system are differentiated into three levels. As shown in the ISM hierarchical model, there were twelve identified barriers at the topmost hierarchical level, namely: 'poor communication with external stakeholders', 'lack of employee training', knowledge about "Green" concept, 'lack of technical expertise', 'lack of interest of banking sector', 'insufficient research on the topic', 'lack of private sector involvement', high switching costs', 'inefficient existing technological structure', 'risk and process issues', 'low return on investment as compared to the cost of green innovations', 'unsupportive organizational structure'-which were derived from four barriers, 'political instability', 'uncertain economic environment', 'lack of provision of government subsidies' and 'absence of regulatory body',-- on the second level of the ISM hierarchical model. The prior literature also supports the current findings. Mumtaz \& Smith (2019) [53] believe that the people of developing countries do not have sufficient knowledge of the green concept. Lack of information and acceptability is one of the main hurdles in adopting a green finance system.

Scholars considered the unsupportive organizational culture an obstacle for the green finance system [44, 54] to arrange training programs for their employees due to limited financial resources, infrastructure, and insufficient existing technological structures [46]. Further, the technology required to support green practices is also complex and requires a developed organizational structure and expertise for its implementation [48]. The employees are not interested in such training due to inadequate knowledge and skill [59]. The private sector is not interested in green projects because they consider them as a high-risky and low-profitable projects [33]. At the country level, no proper regulatory system is developed to monitor green practices, so no green finance system is established [53]. The government support system is weak due to political and economic instability, which is also a hurdle in implementing a green finance system [43, 56].

Meanwhile, at the bottom of the ISM hierarchical model, there are two barriers 'lack of pressure from global organizations' and 'lack of globally available green criterion'. Guild (2020) [42] stated that the absence of pressure from regional and international organizations to adopt green practices is necessary for developing countries to adopt the green finance system. The uniform global standardized system, rules, and regulations for green practices is also required to implement a green finance system $[8,59]$. These are the critical barriers to be considered in adopting a green finance system. All the aforementioned barriers have a strong dependence and driving power, which means that to implement green finance policies in Pakistan fully, the policymakers should pay special attention to these identified factors. These findings also highlight the need to formulate careful strategies to eliminate these barriers, significantly affecting other barriers and themselves.

\section{5-1- Implications of the Study}

Based on the developed model, the current study made the following implications. First, it tries to explain the concept of green finance, which is one of the critical initiatives that can save the environment without hindering economic development and corporate yield. The environmental challenges amplify the economic and social crises in the countries affected by them. Hence, green finance can be a viable way to successfully minimize the damaging effects of climate change on economies. A proper green finance system and considerable investment to support it can only be implemented with a structured policy, knowledge, and technical expertise. It may not be a problem for developed countries, but the barriers to successfully implementing green finance in developing countries demand serious attention from policymakers. Second, it explores the barriers to implementing the green finance system and their interrelationship. It divides the impediments into three categories: organizational, country, and global. It investigates the inner relationships between the identified barriers, which help to transform the traditional financial system into a sustainable green system.

Third, it may be helpful to policymakers and researchers who wish to increase green finance implementation. The green financial industry is rising across all regions of the world, especially after health incidents linked to the COVID19 outbreak. The coronavirus epidemic has, among other factors, intensified some of the crucial challenges behind such issues. One of these key trends is that it has reminded corporations of their social and environmental intent. All businesses should provide a valuable product or service to the customer and deliver this at the lowest environmental expense. In this way, it enables the most significant net environmental benefit. Fourth, greenhouse gas emissions are the primary reason for global warming and climate change [5]. The introduction of technological developments has influenced the world with carbon emissions, rising temperatures, ozone depletion, destruction of natural wealth, erosion and lack of diversity [38]. The creation and usage of resources within safe guidelines is a matter of immediate need. Although there are major challenges on the road to greening, the path towards reduced carbon, clean energy economy has started and quickly accelerated. However, still, this area requires the special attention of the policymakers to deal with it.

Finally, this study provides a way to understand how green finance can be a tool that requires governance and society to retain its emphasis on green accountability. The obstacles would explain why the businesses should start embracing green finance, and those who already do should lift themselves to higher green finance levels. Moreover, businesses who operate in a sustainable, greener way responsibly should be given the ability to receive greater levels of investor interest. It will reduce their cost of capital, so these companies will have a market edge over several of the rivals that are not adopting such green financing concepts over the long term. This study would also highlight that investors should include 
green finance during their investment decisions because if the businesses are not looking at future-proofing their business, particularly for climate change, then it is unintentionally putting the company's future and the environment at risk.

\section{6- Conclusion}

This research aims to identify and formulate a model for barriers to green finance implementation in Pakistan and determine how these barriers interact with each other. The data were collected in two stages: first, an extensive literature review was conducted, which identified the obstacles from the previous literature, then relevant aggregate dimensions were determined from interviews through the Gioia method. Finally, we merged both sets of factors and ended up with eighteen barriers. A panel of fifteen experts was engaged to rank all the barriers. An ISM-based methodology was developed to find out these barriers, which were based on the expert opinions of relevant sectors. A contextual relationship was found between the barriers through the application of ISM, followed by clustering them through MICMAC. The relationships and interaction between those barriers across different levels can be presented by the ISMbased hierarchical model and MICMAC analysis, which shows those barriers' dependence and driving power. The ISM model divided the barriers into three levels: individual or organizational (level 1), country (level 2), and global (level 3). The results suggest that global level factors: lack of pressure from global organizations and unavailability of globally acceptable green criteria are critical to the prevalence of other factors that indicate its centrality to effectively implementing the sustainable green finance system. The developed model helps to design, implement, and promote ecofriendly projects in developing countries.

\section{6-1- Limitations and Future Directions}

Firstly, this study develops the ISM model with 18 identified barriers based on expert's opinions in the context of Pakistan. The identified barriers fall under the linkages cluster. Therefore, it is suggested to future researchers to explore more barriers, particularly in developing countries, to provide a comprehensive view of the implementation of the sustainable green finance system. Secondly, the ISM framework is developed on expert's opinions, which is one of the study's limitations. The scope of the current research can be widened by applying an integrated ISM technique along with multi-criteria decision-making methodology and hierarchical analytical process to get an in-depth understanding of the concept [70]. Structural equation modeling can also be used in the future to make sure the model is correct [73].

\section{7- Declarations}

\section{7-1-Author Contributions}

Conceptualization, K.I.K. and A.N.; methodology, K.I.K. and M.U.S.; software, M.N.M. and A.N.; validation, R.M.D., A.B.C. and J.M.M.; formal analysis, K.I.K. and M.U.S.; investigation, M.N.M. and K.I.K.; resources, R.M.D. and A.B.C.; data curation, X.X.; writing-original draft preparation, K.I.K.; writing-review and editing, A.N.; visualization, J.M.M. and M.U.S.; supervision, K.I.K; project administration, K.I.K. and A.N.; funding acquisition, M.N.M. All authors have read and agreed to the published version of the manuscript.

\section{7-2-Data Availability Statement}

The data presented in this study are available on request from the corresponding author.

\section{7-3-Funding}

The authors received no financial support for the research, authorship, and/or publication of this article.

\section{7-4-Conflicts of Interest}

The authors declare that there is no conflict of interests regarding the publication of this manuscript. In addition, the ethical issues, including plagiarism, informed consent, misconduct, data fabrication and/or falsification, double publication and/or submission, and redundancies have been completely observed by the authors.

\section{8- References}

[1] Wang, L., Vo, X. V., Shahbaz, M., \& Ak, A. (2020). Globalization and carbon emissions: Is there any role of agriculture valueadded, financial development, and natural resource rent in the aftermath of COP21? Journal of Environmental Management, 268, 110712. doi:10.1016/j.jenvman.2020.110712.

[2] Christmann, P., \& Taylor, G. (2017). Globalization and the environment: Strategies for international voluntary environmental initiatives. Corporate Environmental Responsibility, 563-577. doi:10.4324/9781315259277-30.

[3] Zhang, D., Zhang, Z., \& Managi, S. (2019). A bibliometric analysis on green finance: Current status, development, and future directions. Finance Research Letters, 29, 425-430. doi:10.1016/j.frl.2019.02.003. 
[4] Egli, F., Schärer, D., \& Steffen, B. (2022). Determinants of fossil fuel divestment in European pension funds. Ecological Economics, 191. doi:10.1016/j.ecolecon.2021.107237.

[5] Sachs, J. D., Woo, W. T., Yoshino, N., \& Taghizadeh-Hesary, F. (2019). Importance of Green Finance for Achieving Sustainable Development Goals and Energy Security. Handbook of Green Finance (pp. 3-12). doi:10.1007/978-981-13-0227-5_13.

[6] Tol, R. S. J. (2018). The economic impacts of climate change. Review of Environmental Economics and Policy, 12(1), 4-25. doi:10.1093/reep/rex027.

[7] Yanarella, E. J., Levine, R. S., \& Lancaster, R. W. (2009). Green versus sustainability. Sustainability, 2(5), $296-302$. doi:10.1089/SUS.2009.9838.

[8] Chowdhury, T. U., Datta, R., \& Mohajan, H. K. (2013). Green finance is essential for economic development and sustainability. International Journal of Research in Commerce, 3(10), 104-108.

[9] Ahmad, M., Ahmed, Z., Yang, X., Hussain, N., \& Sinha, A. (2021). Financial development and environmental degradation: Do human capital and institutional quality make a difference? In Gondwana Research. doi:10.1016/j.gr.2021.09.012.

[10] Fu, J., \& Ng, A. W. (2020). Sustainable energy and green finance for a low-carbon economy: Perspectives from the greater bay area of China. In Sustainable Energy and Green Finance for a Low-carbon Economy: Perspectives from the Greater Bay Area of China. Springer International Publishing. doi:10.1007/978-3-030-35411-4.

[11] Zafar, S. S., Fiaz, M., Ikram, A., Khan, K. I., \& Qamar, U. M. (2021). Barriers involve in the energy efficiency in the manufacturing industries of Pakistan. International Journal of Energy Economics and Policy, 11(2), $293-299$. doi:10.32479/ijeep.7599.

[12] Monasterolo, I., Roventini, A., \& Foxon, T. J. (2019). Uncertainty of climate policies and implications for economics and finance: An evolutionary economics approach. Ecological Economics, 163, 177-182. doi:10.1016/j.ecolecon.2019.05.012.

[13] Falcone, P. M., \& Sica, E. (2019). Assessing the opportunities and challenges of green finance in Italy: An analysis of the biomass production sector. Sustainability (Switzerland), 11(2), 517. doi:10.3390/su11020517.

[14] Yoshino, N., Schloesser, T., \& Taghizadeh-Hesary, F. (2021). Social funding of green financing: An application of distributed ledger technologies. International Journal of Finance and Economics, 26(4), 6060-6073. doi:10.1002/ijfe.2108.

[15] Rjoub, H., Odugbesan, J. A., Adebayo, T. S., \& Wong, W. K. (2021). Sustainability of the moderating role of financial development in the determinants of environmental degradation: Evidence from turkey. Sustainability (Switzerland), 13(4), 118. doi:10.3390/su13041844.

[16] Liu, N., Liu, C., Xia, Y., Ren, Y., \& Liang, J. (2020). Examining the coordination between green finance and green economy aiming for sustainable development: A case study of China. Sustainability (Switzerland), 12(9), 3717. doi:10.3390/su12093717.

[17] Cui, Y., Geobey, S., Weber, O., \& Lin, H. (2018). The impact of green lending on credit risk in China. Sustainability (Switzerland), 10(6), 2008. doi:10.3390/su10062008.

[18] Taghizadeh-Hesary, F., \& Yoshino, N. (2019). The way to induce private participation in green finance and investment. Finance Research Letters, 31, 98-103. doi:10.1016/j.frl.2019.04.016.

[19] Qin, J., Zhao, Y., \& Xia, L. (2018). Carbon emission reduction with capital constraint under greening financing and cost sharing contract. International Journal of Environmental Research and Public Health, 15(4), 750. doi:10.3390/ijerph15040750.

[20] Tolliver, C., Fujii, H., Keeley, A. R., \& Managi, S. (2021). Green Innovation and Finance in Asia. Asian Economic Policy Review, 16(1), 67-87. doi:10.1111/aepr.12320.

[21] Cui, X., Zhao, T., \& Wang, J. (2021). Allocation of carbon emission quotas in China's provincial power sector based on entropy method and ZSG-DEA. Journal of Cleaner Production, 284. doi:10.1016/j.jclepro.2020.124683.

[22] He, L., Liu, R., Zhong, Z., Wang, D., \& Xia, Y. (2019). Can green financial development promote renewable energy investment efficiency? A consideration of bank credit. Renewable Energy, 143, 974-984. doi:10.1016/j.renene.2019.05.059.

[23] Boubaker, S., Nguyen, D. K., Berensmann, K., \& Lindenberg, N. Green Finance: Across the Universe. Corporate Social Responsibility, Ethics and Sustainable Prosperity, 305-332. doi.org/10.1142/9789811206887_0011

[24] Soundarrajan, P., \& Vivek, N. (2016). Green finance for sustainable green economic growth in India. Agricultural Economics (Czech Republic), 62(1), 35-44. doi:10.17221/174/2014-AGRICECON.

[25] D’Orazio, P., \& Popoyan, L. (2019). Fostering green investments and tackling climate-related financial risks: Which role for macroprudential policies? Ecological Economics, 160, 25-37. doi:10.1016/j.ecolecon.2019.01.029.

[26] Durrani, A., Rosmin, M., \& Volz, U. (2020). The role of central banks in scaling up sustainable finance-what do monetary authorities in the Asia-Pacific region think? Journal of Sustainable Finance and Investment, 10(2), 92-112. doi:10.1080/20430795.2020.1715095. 
[27] Kamran, H. W., Haseeb, M., Nguyen, T. T., \& Nguyen, V. C. (2020). Climate change and bank stability: The moderating role of green financing and renewable energy consumption in ASEAN. doi:10.31219/osf.io/v48fa.

[28] Kirikkaleli, D., \& Adebayo, T. S. (2021). Do renewable energy consumption and financial development matter for environmental sustainability? New global evidence. Sustainable Development, 29(4), 583-594. doi:10.1002/sd.2159.

[29] Bieliński, T., \& Mosionek-Schweda, M. (2018). Green bonds as a financial instrument for environmental projects funding. Unia Europejska. pl, 248(1), 13-21.

[30] Azhgaliyeva, D. (2019). Energy storage and renewable energy deployment: Empirical evidence from OECD countries. Energy Procedia, 158, 3647-3651. doi.org/10.1016/j.egypro.2019.01.897.

[31] Volz, U., Böhnke, J., Eidt, V., Knierim, L., Richert, K., \& Roeber, G.-M. (2015). Financing the Green Transformation — Market Failures, Government Failures and the Role of the State. Financing the Green Transformation, 7-21. doi:10.1057/9781137486127_2.

[32] Jha, N., \& Bhome, S. (2013). A study of green banking trends in India. International Monthly Referred Journal of Research in Management and Technology, 2, 127-132.

[33] Wang, Y., \& Zhi, Q. (2016). The role of green finance in environmental protection: Two aspects of market mechanism and policies. Energy Procedia, 104, 311-316. doi.org/10.1016/j.egypro.2016.12.053.

[34] Peng, H., Luo, X., \& Zhou, C. (2018). Introduction to China's Green Finance System. Journal of Service Science and Management, 11(01), 94-100. doi:10.4236/jssm.2018.111009.

[35] Haleem, A., Sushil, Qadri, M. A., \& Kumar, S. (2012). Analysis of critical success factors of world-class manufacturing practices: An application of interpretative structural modelling and interpretative ranking process. Production Planning and Control, 23(10-11), 722-734. doi:10.1080/09537287.2011.642134.

[36] Dowson, M., Poole, A., Harrison, D., \& Susman, G. (2012). Domestic UK retrofit challenge: Barriers, incentives and current performance leading into the Green Deal. Energy Policy, 50, 294-305. doi:10.1016/j.enpol.2012.07.019.

[37] Lee, J. H., \& Woo, J. (2020). Green new deal policy of South Korea: Policy innovation for a sustainability transition. Sustainability (Switzerland), 12(23), 1-17. doi:10.3390/su122310191.

[38] Zubair Mumtaz, D. M., \& Alexander Smith, D. Z. (2019). Green Finance for Sustainable Development in Pakistan. IPRI Journal, 2, 1-34. doi:10.31945/iprij.190201.

[39] Charles, G., \& Philip, B. (2020). Green Finance: Recent Drifts, Confrontation and Prospect Opportunities for Sustainable Development in India. Mukt Shabd Journal, 9(4), 1854-1865.

[40] Khan, K. I., Babar, Z., Sharif, S., Iqbal, S., \& Khan, M. I. (2021). Going green? Investigating the role of GSCM practices on firm financial and environmental performance through green innovation. International Journal of Procurement Management, 14(6), 681-701. doi:10.1504/IJPM.2021.117894.

[41] Mohd, S., \& Kaushal, V. K. (2018). Green Finance: A Step towards Sustainable Development. MUDRA : Journal of Finance and Accounting, 5(1), 59-74. doi:10.17492/mudra.v5i01.13036.

[42] Guild, J. (2020). The political and institutional constraints on green finance in Indonesia. Journal of Sustainable Finance and Investment, 10(2), 157-170. doi:10.1080/20430795.2019.1706312.

[43] Runhaar, H., Tigchelaar, C., \& Vermeulen, W. J. V. (2008). Environmental leaders: Making a difference. A typology of environmental leaders and recommendations for a differentiated policy approach. Business Strategy and the Environment, 17(3), 160-178. doi:10.1002/bse.520.

[44] Ren, X., Shao, Q., \& Zhong, R. (2020). Nexus between green finance, non-fossil energy use, and carbon intensity: Empirical evidence from China based on a vector error correction model. Journal of Cleaner Production, 277, 122844. doi:10.1016/j.jclepro.2020.122844.

[45] Soedarmono, W., Machrouh, F., \& Tarazi, A. (2011). Bank market power, economic growth and financial stability: Evidence from Asian banks. Journal of Asian Economics, 22(6), 460-470. doi:10.1016/j.asieco.2011.08.003.

[46] Gupta, H., \& Barua, M. K. (2018). A framework to overcome barriers to green innovation in SMEs using BWM and Fuzzy TOPSIS. Science of the Total Environment, 633, 122-139. doi:10.1016/j.scitotenv.2018.03.173.

[47] Banga, J. (2019). The green bond market: a potential source of climate finance for developing countries. Journal of Sustainable Finance and Investment, 9(1), 17-32. doi:10.1080/20430795.2018.1498617.

[48] Ghisetti, C., Mancinelli, S., Mazzanti, M., \& Zoli, M. (2017). Financial barriers and environmental innovations: evidence from EU manufacturing firms. Climate Policy, 17, S131-S147. doi:10.1080/14693062.2016.1242057. 
[49] Frederick, W. C. (1997). Financing change: The financial community, eco-efficiency, and sustainable development. The Journal of Socio-Economics, 26(4), 459-463. doi:10.1016/s1053-5357(97)90007-x.

[50] Petruzzelli, A. M., Dangelico, R. M., Rotolo, D., \& Albino, V. (2011). Organizational factors and technological features in the development of green innovations: Evidence from patent analysis. Innovation: Management, Policy and Practice, 13(3). doi:10.5172/impp.2011.13.3.291.

[51] Matus, K. J. M., Xiao, X., \& Zimmerman, J. B. (2012). Green chemistry and green engineering in China: Drivers, policies and barriers to innovation. Journal of Cleaner Production, 32, 193-203. doi:10.1016/j.jclepro.2012.03.033.

[52] Abuzeinab, A., Arif, M., \& Qadri, M. A. (2017). Barriers to MNEs green business models in the UK construction sector: An ISM analysis. Journal of Cleaner Production, 160, 27-37. doi:10.1016/j.jclepro.2017.01.003.

[53] Zubair Mumtaz, D. M., \& Alexander Smith, D. Z. (2019). Green Finance for Sustainable Development in Pakistan. IPRI Journal, 2, 1-34. doi:10.31945/iprij.190201.

[54] Rahman, T., Ali, S. M., Moktadir, M. A., \& Kusi-Sarpong, S. (2020). Evaluating barriers to implementing green supply chain management: An example from an emerging economy. Production Planning and Control, 31(8), 673-698. doi:10.1080/09537287.2019.1674939.

[55] Choi, C. (2009). Removing Market Barriers to Green Development: Principles and Action Projects to Promote Widespread Adoption of Green Development Practices. Journal of Sustainable Real Estate, 1(1), 107-138. doi:10.1080/10835547.2009.12091785.

[56] Samari, M., Godrati, N., Esmaeilifar, R., Olfat, P., \& Shafiei, M. W. M. (2013). The investigation of the barriers in developing green building in Malaysia. Modern Applied Science, 7(2), 1-10. doi:10.5539/mas.v7n2p1.

[57] Nguyen, T. C., Chuc, A. T., \& Dang, L. N. (2019). Green Finance in Viet Nam. In Handbook of Green Finance (pp. 675-705). doi:10.1007/978-981-13-0227-5_35.

[58] Yoshino, N., Taghizadeh-Hesary, F., \& Nakahigashi, M. (2019). Modelling the social funding and spill-over tax for addressing the green energy financing gap. Economic Modelling, 77, 34-41. doi:10.1016/j.econmod.2018.11.018.

[59] Sareen, A., \& Sharma, S. (2021). Assessing Financial Distress and Predicting Stock Prices of Automotive Sector: Robustness of Altman Z-score. Vision: The Journal of Business Perspective, 097226292199092. doi:10.1177/0972262921990923.

[60] Nag, R., \& Gioia, D. A. (2012). From common to uncommon knowledge: Foundations of firm-specific use of knowledge as a resource. Academy of Management Journal, 55(2), 421-457. doi:10.5465/amj.2008.0352.

[61] Gioia, D. A., Corley, K. G., \& Hamilton, A. L. (2013). Seeking Qualitative Rigor in Inductive Research: Notes on the Gioia Methodology. Organizational Research Methods, 16(1), 15-31. doi:10.1177/1094428112452151.

[62] Nath, V., Kumar, R., Agrawal, R., Gautam, A., \& Sharma, V. (2014). Impediments to Adoption of Green Products: An ISM Analysis. Journal of Promotion Management, 20(5), 501-520. doi:10.1080/10496491.2014.946200.

[63] Gholami, H., Rezaei, G., Saman, M. Z. M., Sharif, S., \& Zakuan, N. (2016). State-of-the-art Green HRM System: Sustainability in the sports center in Malaysia using a multi-methods approach and opportunities for future research. Journal of Cleaner Production, 124, 142-163. doi:10.1016/j.jclepro.2016.02.105.

[64] Makki, A. A., Alidrisi, H., Iqbal, A., \& Al-Sasi, B. O. (2020). Barriers to Green Entrepreneurship: An ISM-Based Investigation. Journal of Risk and Financial Management, 13(11), 249. doi:10.3390/jrfm13110249.

[65] Mojumder, A., \& Singh, A. (2021). An exploratory study of the adaptation of green supply chain management in construction industry: The case of Indian Construction Companies. Journal of Cleaner Production, $295,295$. doi:10.1016/j.jclepro.2021.126400.

[66] Sarkar, A., Qian, L., Peau, A. K., \& Shahriar, S. (2021). Modeling drivers for successful adoption of green business: an interpretive structural modeling approach. Environmental Science and Pollution Research, 28(1), 1077-1096. doi:10.1007/s11356-020-10490-z.

[67] Mathiyazhagan, K., Govindan, K., NoorulHaq, A., \& Geng, Y. (2013). An ISM approach for the barrier analysis in implementing green supply chain management. Journal of Cleaner Production, 47, 283-297. doi:10.1016/j.jclepro.2012.10.042.

[68] Awuzie, B. O., \& Abuzeinab, A. (2019). Modelling organisational factors influencing sustainable development implementation performance in higher education institutions: An interpretative structural modelling (ISM) approach. Sustainability (Switzerland), 11(16), 4312. doi:10.3390/su11164312.

[69] Priya, S. S., Priya, M. S., Jain, V., \& Dixit, S. K. (2021). An assessment of government measures in combatting COVID-19 using ISM and DEMATEL modelling. Benchmarking. doi:10.1108/BIJ-05-2021-0244. 
[70] Stireman, J. O., Dyer, L. A., Janzen, D. H., Singer, M. S., Lill, J. T., Marquis, R. J., Ricklefs, R. E., Gentry, G. L., Hallwachs, W., Coley, P. D., Barone, J. A., Greeney, H. F., Connahs, H., Barbosa, P., Morais, H. C., \& Diniz, I. R. (2005). Climatic unpredictability and parasitism of caterpillars: Implications of global warming. Proceedings of the National Academy of Sciences of the United States of America, 102(48), 17384-17387. doi:10.1073/pnas.0508839102.

[71] Rosales, J. (2008). Economic growth, climate change, biodiversity loss: Distributive justice for the global north and south. Conservation Biology, 22(6), 1409-1417. doi:10.1111/j.1523-1739.2008.01091.x.

[72] Fankhauser, S., \& Tol, R. S. J. (2005). On climate change and economic growth. Resource and Energy Economics, 27(1), 1-17. doi:10.1016/j.reseneeco.2004.03.003.

[73] Raut, R. D., Narkhede, B., \& Gardas, B. B. (2017). To identify the critical success factors of sustainable supply chain management practices in the context of oil and gas industries: ISM approach. Renewable and Sustainable Energy Reviews, 68, 33-47. doi:10.1016/j.rser.2016.09.067. 


\section{Appendix I}

Table A1. Characteristics of interviewees

\begin{tabular}{|c|c|c|c|c|c|}
\hline Respondents & Current Position & Gender & Interview Medium & $\begin{array}{c}\text { Work Experience in Current } \\
\text { Position }\end{array}$ & Total Work Experience \\
\hline 1 & Foreign Trade Officer & Male & Face to Face & 1.5 & 10 \\
\hline 2 & Senior Accountant & Male & Face to Face & 1 & 6 \\
\hline 3 & Account Management Officer & Female & Face to Face & 5 & 8 \\
\hline 4 & PA Area Manager & Male & Face to Face & 6 & 7 \\
\hline 5 & Co-ordinator & Female & Telephonic & 5 & 8 \\
\hline 6 & Account Management Officer & Male & Telephonic & 4 & 8 \\
\hline 7 & Member of Legal Advisory Board & Male & Face to Face & 7 & 17 \\
\hline 8 & Business Development Officer & Female & Face to Face & 1 & 5 \\
\hline 9 & Deputy Director & Male & Face to Face & 5 & 13 \\
\hline 10 & 2nd Grade Officer & Male & Face to Face & 5 & 12 \\
\hline 11 & Senior Manager & Male & Telephonic & 3 & 12 \\
\hline 12 & 1st Grade Officer & Male & Written & 3 & 15 \\
\hline 13 & 1st Grade Officer & Female & Telephonic & 5 & 17 \\
\hline 14 & 2nd Grade Officer & Male & Video Call & 4 & 10 \\
\hline 15 & 2nd Grade Officer & Female & Video Call & 4 & 11 \\
\hline 16 & Business Development Executive & Female & Written & 5 & 13 \\
\hline 17 & Credit Sales Executive & Male & Video Call & 3 & 9 \\
\hline 18 & Insurance Sales Executive & Male & Written & 5 & 12 \\
\hline 19 & Senior Sales Manager & Male & Face to Face & 2 & 14 \\
\hline 20 & Assistant Manager & Male & Video Call & 7 & 13 \\
\hline 21 & Corporate Credit Risk Manager & Male & Face to Face & 1 & 10 \\
\hline
\end{tabular}

Table A2. Details of panel of experts

\begin{tabular}{ccccc}
\hline Expert & Occupation & Qualification & Experience & Field \\
\hline 1 & Deputy Director of State Bank & Ph.D. & 23 & Bamking \\
2 & Senior Credit Manager & MBA & 17 & Bamking \\
3 & Area Manager in Loans & MBA & 15 & Bamking \\
4 & Senior Business Development Manager & MBA & 11 & Bamking \\
5 & Associate Professor & Ph.D. & 20 & Academicians \\
6 & Associate Professor & Ph.D. & 18 & Academicians \\
7 & Assistant Professor & M.Phil. & 23 & Academicians \\
8 & Assistant Professor & M.Phil. & 10 & Academicians \\
9 & Assistant Director & M.S. & 16 & Environmentalist \\
10 & Environmental Officer & M.S. & 12 & Environmentalist \\
11 & Environmental Officer & M.S. & 14 & Environmentalist \\
12 & Senior Researcher & M.A. & 16 & Economist \\
13 & Data Analyst & M.A. & 12 & Economist \\
14 & Corporate Manager & CFA & 13 & Other \\
15 & Social Activist & B,A & 10 & Other \\
\hline
\end{tabular}

